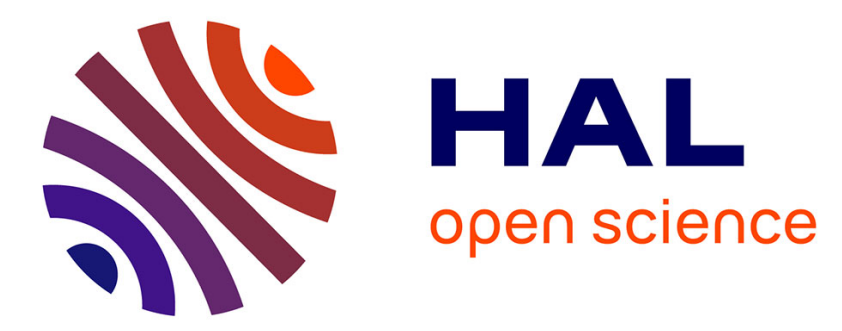

\title{
Investigation on the fine structure of sea breeze during ESCOMPTE experiment
}

\author{
V. Puygrenier, Fabienne Lohou, Bernard Campistron, F. Saïd, G. Pigeon, B. \\ Bénech, Dominique Serça
}

\section{> To cite this version:}

V. Puygrenier, Fabienne Lohou, Bernard Campistron, F. Saïd, G. Pigeon, et al.. Investigation on the fine structure of sea breeze during ESCOMPTE experiment. Atmospheric Research, 2005, 74 (1-4), pp.329-353. 10.1016/j.atmosres.2004.06.011 . hal-00135874

\section{HAL Id: hal-00135874 \\ https://hal.science/hal-00135874}

Submitted on 15 Jun 2021

HAL is a multi-disciplinary open access archive for the deposit and dissemination of scientific research documents, whether they are published or not. The documents may come from teaching and research institutions in France or abroad, or from public or private research centers.
L'archive ouverte pluridisciplinaire HAL, est destinée au dépôt et à la diffusion de documents scientifiques de niveau recherche, publiés ou non, émanant des établissements d'enseignement et de recherche français ou étrangers, des laboratoires publics ou privés.

\section{(c)(1)}

Distributed under a Creative Commons Attribution| 4.0 International License 


\title{
Investigation on the fine structure of sea-breeze during ESCOMPTE experiment
}

\author{
V. Puygrenier,*, F. Lohou ${ }^{\mathrm{a}}$, B. Campistron ${ }^{\mathrm{a}}$, F. Said ${ }^{\mathrm{a}}$, \\ G. Pigeon ${ }^{\mathrm{b}}, \mathrm{B}$. Bénech ${ }^{\mathrm{a}}, \mathrm{D}$. Serça ${ }^{\mathrm{a}}$ \\ a Laboratoire d'Aérologie, Centre de Recherches Atmosphériques, UMR 5560 CNRS/UPS, \\ 65300 Lannemezan, France \\ ${ }^{\mathrm{b}}$ Météo France, Centre National de Recherches Météorologiques, Toulouse, France
}

Surface and remote-sensing instruments deployed during ESCOMPTE experiment over the Marseille area, along the Mediterranean coast, were used to investigate the fine structure of the atmospheric boundary layer (ABL) during sea-breeze circulation in relation to pollutant transport and diffusion. Six sea-breeze events are analyzed with a particular focus on 25 June 2001.

Advection of cool and humid marine air over land has a profound influence on the daytime ABL characteristics. This impact decreases rapidly with the inland distance from the sea. Nearby the coast ( $3 \mathrm{~km}$ inland), the mixing height $Z i$ rises up to $750 \mathrm{~m}$ and falls down after 15:00 (UT) when the breeze flow reaches its maximum intensity. A more classical evolution of the ABL is observed at only $11-\mathrm{km}$ inland where $Z i$ culminates in the morning and stabilizes in the afternoon at about 1000 $\mathrm{m}$ height.

Fine inspection of the data revealed an oscillation of the sea-breeze with a period about $2 \mathrm{~h}$ $47 \mathrm{~min}$. This feature, clearly discernable for 3 days at least, is present in several atmospheric variables such as wind, temperature, not only at the ground but also aloft in the ABL as observed by sodar/RASS and UHF wind profilers. In particular, the mixing height $Z i$ deduced from UHF profilers observations is affected also by the same periodicity. This pulsated sea-breeze is observed principally above Marseille and, at the northern and eastern shores of the Berre pond.

* Corresponding author. Centre de Recherches Atmosphériques, 8 route de Lannemezan, 65300 Campistrous, France. Tel.: +33 562406105; fax: +33 562406101.

E-mail address: puyv@aero.obs-mip.fr (V. Puygrenier). 
In summary, the periodic intrusion over land of cool marine air modifies the structure of the ABL in the vicinity of the coast from the point of view of stability, turbulent motions and pollutants concentration. An explanation of the source of this pulsated sea-breeze is suggested.

Keywords: Atmospheric boundary layer; Sea-breeze oscillations; Remote sensing measurements; Pollution

\section{Introduction}

For evident reasons of commercial exchanges, the most important industrial complexes and megalopolis are located along maritime coastal region. Under high pressure conditions, these densely urbanized zones are affected by pollution episodes during land and sea breeze circulations, which mix continental and maritime air with very different physical characteristics. A better understanding of these breeze flows is of primary importance to ameliorate pollution peaks prediction and to evaluate air quality policy in coastal areas. The international ESCOMPTE campaign was conducted in summer 2001 to investigate pollutant transport, diffusion and emission in the Marseille/Berre Mediterranean region, one of the most polluted area in France (http:// medias.obs-mip.fr./Escompte). The main objective of ESCOMPTE is to assess numerical modeling of atmospheric pollution (Cros et al., 2004). Together with the ESCOMPTE project, the urban boundary layer (UBL) experiment (Mestayer et al., 2004) deployed specific facilities within Marseille in order to document the fine-scale urban low-level flow. The work presented here is an experimental study focusing on breeze circulation observed during ESCOMPTE and its influence on the dynamics and pollution of the atmospheric boundary layer (ABL).

The atmospheric baroclinicity induced by the different response of the land and sea surface to the diurnal cycle of heating and cooling is the source of the breeze circulation, roughly transverse to the coast. During daytime, sea-breeze advects cool and humid air over land whereas during night a reverse flow blows from land to sea. In the standard description of coastal breeze, this dynamical circulation at low levels is completed by a return flow seaward or landward at upper levels during the day and the night, respectively. Finkele et al. (1995) observed such a sea-breeze circulation cell with an instrumented aircraft. However, they pointed out that days without a return flow in upper levels can occur. Sea-breeze is a mesoscale phenomenon, which extends far over the sea and to several tens of kilometers inland. For instance, Simpson et al. (1977) reported several cases of sea-breeze reaching $100 \mathrm{~km}$ inland. The moving leading edge of a sea-breeze, the separation between maritime and continental air mass, can be considered as a front, detected by a jump of specific humidity, temperature, wind velocity and wind direction veering. According to Simpson et al. (1977), a sea-breeze front is equivalent to a gravity current constituted by a head whose depth is about twice the height of the trailing flow. However, Yoshikado and Kondo (1989) observed non-frontal sea-breeze cases with no clear changes of thermodynamical and dynamical parameters.

Coastal zones are marked by sharp surface temperature and roughness change between land and sea. Convection and mechanical turbulence mix marine and continental air over 
land, and contribute to the formation of the ABL during the sea-breeze flow. The top of the ABL $(\mathrm{Zi})$ grows from the coastline up to an equilibrium height inland. This "equilibrium height" corresponds to the height of the inland mixed-layer. The equilibrium height and the distance from the coast necessary to reach it, varied in different studies. An example of such variability is presented by Raynor et al. (1979). They analyzed 28 sea-breeze cases with intensive aircraft, towers and pilot balloons measurements. The equilibrium heights ranged from 480 to greater than $900 \mathrm{~m}$ and the distances from the coast at which they were reached, ranged from 5 to $40 \mathrm{~km}$ (sometimes greater). According to the thermal stability conditions over the sea, the ABL starts growing up at the shoreline either from zero-level (stable onshore flow) or from the height of the offshore boundary layer (neutral onshore flow). The impacts of stable and neutral sea-breeze flow on the ABL were largely studied: Venkatram (1986), Gryning and Batchvarova (1990) for the first ones, and Källstrand and Smedman (1997) and Luhar (1998) for the seconds. Urban areas and complex coastal geography (ragged shoreline and mountains) also affect the ABL characteristics under seabreeze circulation. For example, Cenedese and Monti (2003) showed that convergence due to the interaction between the urban heat island and sea-breeze flow, enhances $Z i$ height. Bastin et al. (2004) observed that the narrowing of the Durance valley accelerates and deepens the sea-breeze flow and increases ABL depth. Other studies focused on the interaction between the sea-breeze and the ABL characteristics in complex geography and urban areas (Melas et al., 1995; Levitin and Kambezidis, 1997; Batchvarova et al., 1999; Liu et al., 2001).

Mesoscale structure of the sea-breeze circulation and ABL is abundantly described in the literature. The present paper describes and analyses the pulsated nature of the seabreeze observed during the ESCOMPTE experiment. The first part presents briefly the ESCOMPTE experiment and the instruments used for this work. The second part, which gives an overview of the meteorological conditions encountered during the campaign, shows sea-breeze occurrence in this region. A diurnal sea-breeze circulation and its effect on atmospheric boundary layer is then presented with the example of 25 June 2001. The third part is devoted to the analysis of the sea-breeze at a smaller temporal-scale in the vicinity of the coast. The study of 25 June 2001 will be gone into deeper because a $2 \mathrm{~h}$ 47 min period oscillation of the sea-breeze flow is clearly observed above Marseille and in other sites of ESCOMPTE area. An analysis of several sea-breeze days is also made to determine the occurrence of this phenomenon for the whole campaign. The last part discusses on the impact of a pulsated sea-breeze on the coastal low atmosphere of Marseille from the stability, ABL depth and pollution point of view. An hypothesis on the source of this particular sea-breeze behavior is proposed based on vertical motions measurements made above Marseille city.

\section{ESCOMPTE and UBL experiments (13 June-14 July 2001)}

This study concerns a coastal zone of the ESCOMPTE domain, which includes the Greater Marseille. Alps foothills reaching $500 \mathrm{~m}$ in the north and east of the domain, ragged shoreline and the Berre pond in the central part of the domain make the topography of this region particularly complex (cf. Fig. 1, diagram a). Marseille itself is surrounded by 
(a)

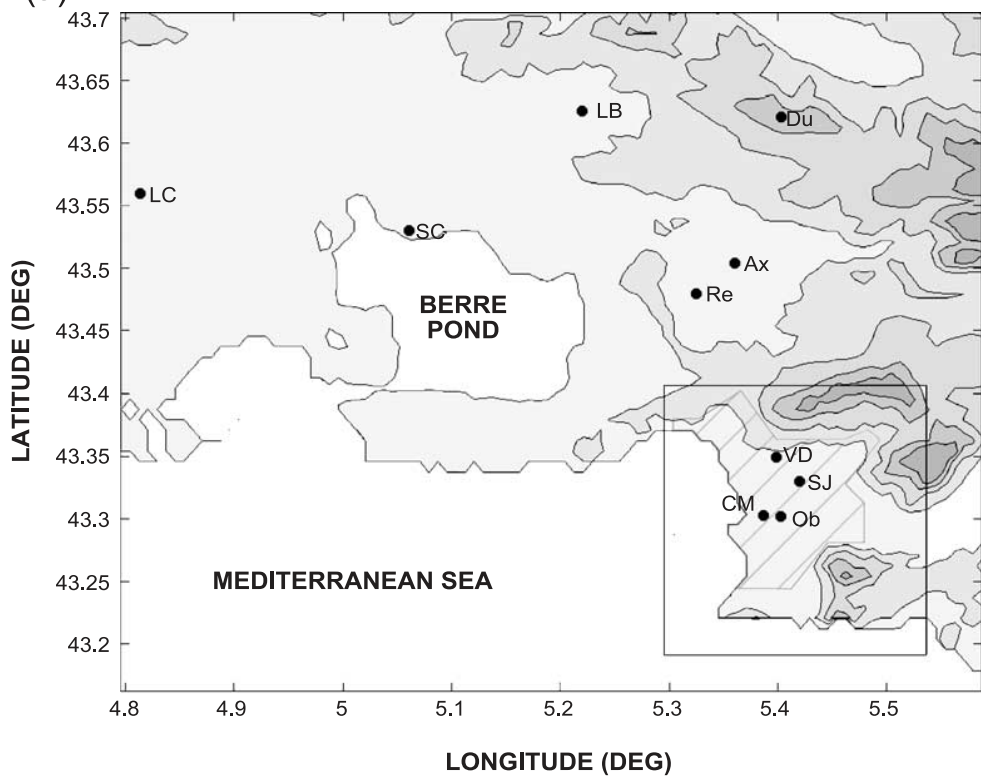

(b)

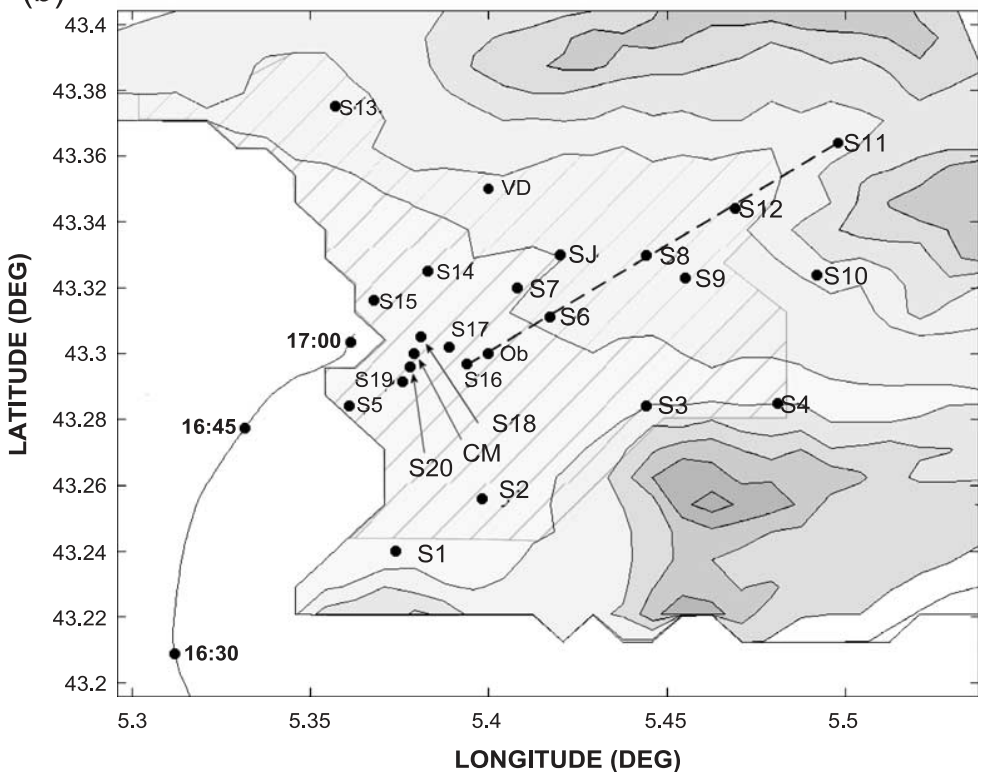

Fig. 1. (a) Part of ESCOMPTE domain with ground elevation above $200 \mathrm{~m}$; contours are every $100 \mathrm{~m}$. The square delineates roughly the Great Marseille. (b) Marseille with ground elevation above $100 \mathrm{~m}$; contours are every 100 $\mathrm{m}$. Ferry route is indicated by the line with its location at 16:30, 16:45 and 17:00 (UT). The dashed line allows to locate easily the stations used in Fig. 9. (On both diagrams, instrumented sites are mentioned by acronyms (see Table 1) and hatched area represents the extent of Marseille agglomeration). 
hills in the southern, eastern and northern sides, and presents a north-south coastline with the Mediterranean sea in its western side and a west-east coastline in the south (cf. Fig. 1, diagram $b)$.

Wind profilers (UHF, sodars and sodar/RASS) data and ground stations measuring mean and turbulent meteorological parameters are essentially used here. The instrumented sites are positioned in Fig. 1 (diagram a). Their main characteristics such as site type (defined as rural, suburban or urban), height above sea level, distance to the nearest shoreline (Berre pond or Mediterranean coast) and the experimental set-up are reported in Table 1.

\subsection{Surface in situ measurements}

For each meteorological ground station of the ESCOMPTE area, wind velocity and direction, temperature and humidity of the air were measured on a mast of $10 \mathrm{~m}$ height, except at $\mathrm{CM}$ where the mast was $26 \mathrm{~m}$ height. In the urban area at $\mathrm{Ob}, \mathrm{SJ}$ and $\mathrm{CM}$ site (see Table 1 for the explanation of the site acronyms), the masts were installed on the roofs of buildings. The data were averaged in real time over a period of 10 or $15 \mathrm{~min}$. Additionally, a dense network made of 20 surface stations (noted S1 to S20 in Fig. 1, diagram b) was deployed in the streets of Marseille for a fine scale documentation of the temperature and humidity at a $6 \mathrm{~m}$ height with a sampling period of $10 \mathrm{~min}$.

Moreover, surface energy budget was obtained at stations of Ob, SJ, CM, LC, SC but only data collected by CM and SC stations are used in this study to characterize urban and rural zones, respectively. Upward and downward infrared and global radiation components were measured. Three-dimensional (3-D) sonic anemometer and krypton sensor provided

Table 1

Characteristics and instrumental equipment of the different sites mentioned on Fig. 1

\begin{tabular}{llllllll}
\hline Sites & $\begin{array}{l}\text { Laboratory } \\
\text { in charge }\end{array}$ & $\begin{array}{l}\text { Acronyms } \\
\text { used in } \\
\text { Fig. 1 }\end{array}$ & $\begin{array}{l}\text { Distance } \\
\text { to the nearest } \\
\text { shoreline }(\mathrm{km})\end{array}$ & $\begin{array}{l}\text { Height } \\
\text { above sea } \\
\text { level }(\mathrm{m})\end{array}$ & $\begin{array}{l}\text { Type of } \\
\text { ground }\end{array}$ & $\begin{array}{l}\text { Remote } \\
\text { sensing } \\
\text { measurements }\end{array}$ & $\begin{array}{l}\text { In situ } \\
\text { measurements }\end{array}$ \\
\hline La Crau & CNRM $^{\mathrm{a}}$ & LC & 17 & 10 & Rural & & $\mathrm{M}+\mathrm{T}$ \\
La Barben & CNRM $^{\mathrm{a}}$ & $\mathrm{LB}$ & 14 & 165 & Rural & & $\mathrm{M}+\mathrm{T}$ \\
Dupail & $\mathrm{CNRM}^{\mathrm{a}}$ & $\mathrm{Du}$ & 21 & 495 & Rural & & $\mathrm{M}$ \\
Saint Chamas & EDF $^{\mathrm{b}}$ & $\mathrm{SC}$ & 0 & 20 & Rural & Sodar and UHF & $\mathrm{M}+\mathrm{T}$ \\
Aix les Milles & LSEET $^{\mathrm{c}}$ & $\mathrm{Ax}$ & 11 & 103 & Rural & UHF & $\mathrm{M}$ \\
Réaltor & $\mathrm{CNRM}^{\mathrm{a}}$ & $\mathrm{Re}$ & 8 & 162 & Rural & & $\mathrm{M}$ \\
Vallon Dol & $\mathrm{CNRM}^{\mathrm{a}}$ & $\mathrm{VD}$ & 5 & 130 & Suburban & Sodar+RASS & $\mathrm{M}$ \\
Saint Jérome & $\mathrm{ECN}^{\mathrm{d}}$ & $\mathrm{SJ}$ & 6 & 130 & Urban & Sodar & $\mathrm{M}+\mathrm{T}$ \\
Observatoire & $\mathrm{LA}^{\mathrm{e}}$ & $\mathrm{Ob}$ & 3 & 60 & Urban & UHF & $\mathrm{M}+\mathrm{T}$ \\
Central Mast & $\mathrm{IU}^{\mathrm{f}}$ & $\mathrm{CM}$ & 2 & 70 & Urban & & $\mathrm{M}+\mathrm{T}$ \\
\hline
\end{tabular}

$\mathrm{M}$ and $\mathrm{T}$ indicate mean and turbulent measurements of ground stations, respectively.

a Centre National de Recherches Météorologiques.

b Electricité De France.

c Laboratoire des Sondages Electromagnétiques de l'Environnement Terrestre.

d Ecole Centrale de Nantes.

e Laboratoire d'Aérologie.

${ }^{\mathrm{f}}$ Indiana University. 
temperature, 3-D wind components and humidity turbulent fluctuations with a $0.1 \mathrm{~s}$ temporal resolution. Turbulent fluxes were calculated with eddy-correlation method.

Low level turbulent fluxes over urban areas are difficult to measure because of the heterogeneity of the urban canopy. On the one hand, the instruments have to be placed sufficiently far from the ground to measure representative fluxes of the area. On the other hand, the fetch requires the instruments to be located far enough downwind from an eventual disturbance caused by adjacent areas. On the CM mast, two flux sensors were mounted at 44 and 38 m AGL (Grimmond et al., 2002; Mestayer et al., 2004). The mean height of the surrounding buildings was $16 \mathrm{~m}$. The ratio between fluxes measured at the two levels was nearly equal to one, suggesting that both are in the inertial sublayer. Grimmond et al. (2002) conclude that, given the close spacing of the buildings in the city center, measurement heights larger than 1.5 times the mean building height seem appropriate for the CM site.

\subsection{Remote-sensing facilities}

The study makes use of observations collected by three identical UHF-band wind profilers located at $\mathrm{Ob}, \mathrm{SC}$ and $\mathrm{Ax}$, and by three Doppler sodars at VD, SJ and SC. At VD vertical profiles of temperature are obtained with the Radio Acoustic Sounding System (RASS) technique based on the reflection of a radio wave on the sodar acoustic wave front (for more explanation, see Girard-Ardhuin et al., 2003). Temporal and vertical resolution and the vertical coverage of these remote-sensing devices are given in Table 2. Vertical profiles of the reflectivity, the three components of the wind and the Doppler spectral width are the standard data provided by these instruments. The turbulent kinetic energy dissipation rate $\epsilon$ can be deduced from the UHF Doppler spectral width (Jacoby-Koaly et al., 2002).

In clear air, UHF radar and sodar echoes come from the scattering of the incident wave by spatial irregularities, at the scale of half the instrument wavelength, of the air refractive index $n$ related to temperature and water vapor fluctuations. Sodars are only sensitive to temperature fluctuations whereas humidity fluctuations predominate strongly for UHF backscatterings in the first $5 \mathrm{~km}$ of the atmosphere. Sodar and UHF profiler reflectivity are proportional to the air refractive index structure constant $C_{n}^{2}$ (which reduces to $C_{T}^{2}$ for sodar). Strong $\mathrm{C}_{\mathrm{n}}^{2}$ values are favored by high vertical gradient of temperature and humidity and the presence of strong turbulent mixing. These conditions are usually met at the ABL top $Z i$, which then appears as the level of a local UHF reflectivity maximum. It is then possible to follow the daytime ABL development in the UHF profiler time-height crosssections with an accuracy in $\mathrm{Zi}$ measurement of the order of half the radar pulse length (here 75 m) (Angevine et al., 1994; Heo et al., 2003).

Table 2

Vertical and temporal resolution, and vertical coverage of the profilers

\begin{tabular}{llll}
\hline Profilers & Vertical resolution $(\mathrm{m})$ & Temporal resolution $(\mathrm{min})$ & Vertical coverage $(\mathrm{m})$ \\
\hline UHF & 75 & 5 & 100 up to $2000 / 3000$ \\
Sodar & 50 & 15 & 50 up to 600 \\
RASS & 50 & 15 & 100 up to 800 \\
\hline
\end{tabular}


The ability of UHF radar to detect rain of even weak intensity was used, in comparison with drop size distribution measurements at the ground obtained by a disdrometer, to calibrate the reflectivity values of the wind profiler located at SC (Campistron et al., 1997). The mean reflectivity vertical profile over the whole campaign of the calibrated UHF radar was then compared to the mean vertical profiles obtained by the other UHF radars in order, assuming similarity of the data on the average, to get their own calibration constant. Sodar reflectivity is presented as uncalibrated $\mathrm{C}_{\mathrm{T}}^{2}$ since we have no guarantee of the manufacturers that these commercial instruments were properly calibrated.

\section{Meteorological conditions and general sea-breeze circulation characteristics}

After a rapid presentation of the general meteorological conditions encountered during ESCOMPTE, the study of 25 June 2001 will illustrate a sea-breeze circulation and its impact on the ABL vertical development.

\subsection{Overview of the campaign}

The period and the site of the ESCOMPTE campaign were particularly favorable to pollution events study. In this context, five intensive observation periods (IOPs) were carried out with different local meteorological conditions detailed in the general paper presented by Cros et al. (2004).

As the present study is related to breeze circulations characterized among other things by wind rotation, Fig. 2 shows wind direction observed at $\mathrm{Ob}$ site in Marseille during the whole campaign. The IOPs periods are indicated by horizontal arrows. This figure allows to detect breeze occurrence through the diurnal cycle of wind direction. The first period (IOP1) of the experiment is mostly associated with northwesterly wind characteristic called Mistral in that region (Corsmeier et al., 2004). During IOP2a, IOP2b and IOP3, breeze circulations occurrence is maximum while a westerly to northwesterly synoptic wind has a clear impact over Marseille surface at the end of the experiment (IOP4).

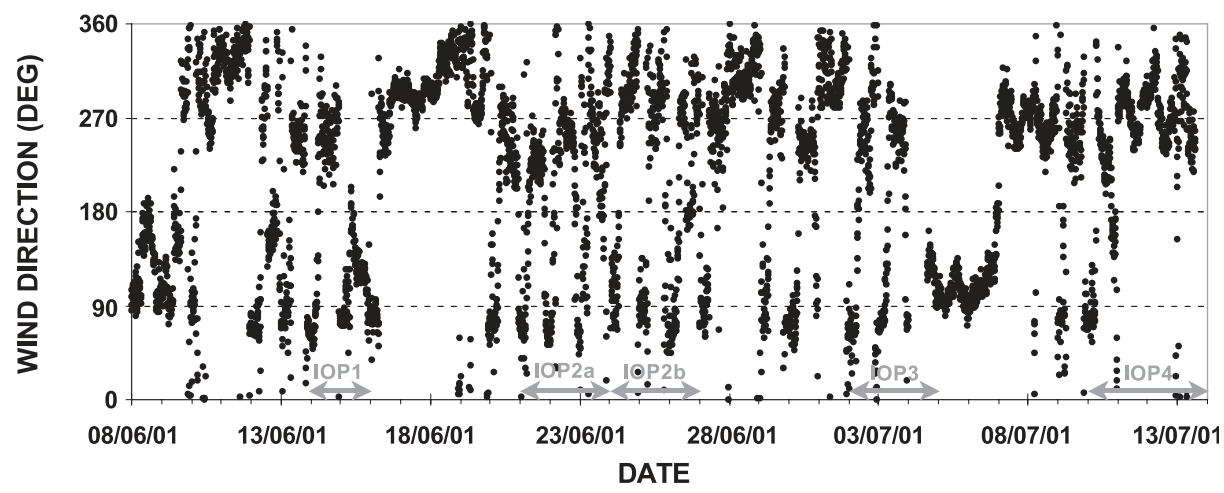

Fig. 2. Time-series of the wind direction measured at Ob during ESCOMPTE campaign. Horizontal arrows at the bottom indicate each IOP duration. 
The complexity of the shoreline orientation and region topography (cf. Fig. 1) induces different sea-breeze direction at the measurement sites. Fig. 3 shows the surface wind roses at $\mathrm{SC}$ and $\mathrm{Ob}$. Whereas the sea-breeze has a southerly direction at $\mathrm{SC}\left(220^{\circ}\right)$, the ground station in Marseille measured a westerly sea-breeze $\left(280^{\circ}\right)$. Besides the breeze circulation, the region is often under Mistral wind influence. Such dynamical conditions are frequently observed in SC with high velocity (exceeding $10 \mathrm{~m} \mathrm{~s}^{-1}$ ) and a northwesterly direction. Mistral wind is not so clearly apparent over Marseille because of the sheltering effect of the hills surrounding the city.

Ten days with a well-established breeze circulation were observed over Marseille region during the campaign, but only six of them have been analyzed here: 20, 24, 25, 26, 27 and 29 June 2001. The 4 other days have been left out because of none available data or instruments failure. All the synoptic and local characteristics over Marseille of the 6 remaining days are summarized in Table 3 . The synoptic wind speed was always inferior to $17 \mathrm{~m} \mathrm{~s}^{-1}$ with a direction varying between west and north, and global radiation values were higher than $880 \mathrm{~W} \mathrm{~m}^{-2}$, with the exception of 27 June 2001 mainly cloudy with southerly wind.

Land and sea surface temperature (LST and SST) over ESCOMPTE area were deduced from NOAA AVHRR observations. It was the only mean to get an idea of the thermal gradient between land and sea, which is the source of the sea-breeze dynamics. SSTs were retrieved with the Mc Clain et al. (1985) formula and LSTs with Becker and Li (1990) and Van de Griend and Owe (1993) algorithms. Usually, LST is much more difficult to evaluate than SST. According to Kerr et al. (2002), the algorithms used in that case are robust and give good results. Table 3 presents mean values of SST, LST and temperature difference LST-SST calculated in a rectangle positioned between $5^{\circ}$ and $5.6^{\circ}$ longitude and $43.15^{\circ}$ and $43.4^{\circ}$ latitude. As expected, values of LST are dependent on global radiation; maxima of LST occur on 20 June and 29 June 2001 with 31.2 and $33.3{ }^{\circ} \mathrm{C}$ when
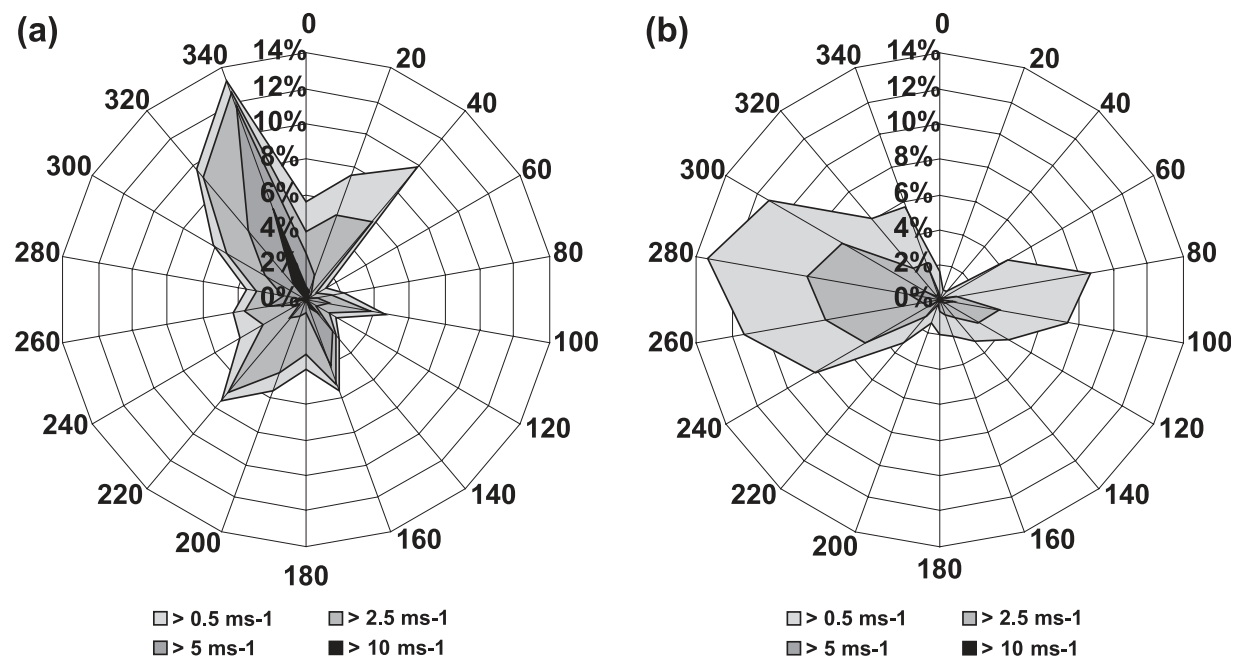

Fig. 3. Wind roses for the whole ESCOMPTE campaign representing the occurrence of the wind episodes in percentage: (a) at $\mathrm{SC}$ and (b) at $\mathrm{Ob}$. 
Table 3

Synoptic and local parameters observed at Marseille for 6 days with sea-breeze circulation

\begin{tabular}{|c|c|c|c|c|c|c|}
\hline & June 20th & June 24th & June 25 th & June 26th & June 27 th & June 29th \\
\hline $\begin{array}{l}\text { Synoptic wind direction at } \\
12: 00(\mathrm{UT}) \text { and } 500 \mathrm{hPa}\left({ }^{\circ}\right)\end{array}$ & $315-360$ & $270-315$ & 315 & 270 & $180-225$ & 315 \\
\hline $\begin{array}{l}\text { Synoptic wind velocity at } \\
12: 00(\mathrm{UT}) \text { and } 500 \mathrm{hPa}\left(\mathrm{m} \mathrm{s}^{-1}\right)\end{array}$ & 17 & 13 & 13 & 6 & 17 & 6 \\
\hline Global radiation maxima $\left(\mathrm{W} \mathrm{m}^{-2}\right)$ & 968 & 889 & 881 & 899 & clouds & 922 \\
\hline $\begin{array}{l}\text { SST daily composition with } \\
\text { NOAA observation }\left({ }^{\circ} \mathrm{C}\right)\end{array}$ & 17.5 & 20.7 & 20.7 & 22 & 21.9 & 23.6 \\
\hline $\begin{array}{l}\text { LST daily composition with NOAA } \\
\text { observation }\left({ }^{\circ} \mathrm{C}\right) \text { around noon }\end{array}$ & 31.2 & 28.7 & 28.4 & 30.6 & 25.1 & 33.3 \\
\hline $\begin{array}{l}\text { Horizontal temperature } \\
\quad \text { difference: LST-SST }\left({ }^{\circ} \mathrm{C}\right)\end{array}$ & 13.7 & 8 & 7.7 & 8.6 & 3.2 & 9.8 \\
\hline $\begin{array}{l}\text { Wind velocity at } \mathrm{Ob} \text { averaged } \\
\text { over } 08: 00-18: 00 \text { (UT) }\left(\mathrm{m} \mathrm{s}^{-1}\right)\end{array}$ & 2.4 & 2.2 & 2.0 & 2.0 & 2.4 & 2.4 \\
\hline $\begin{array}{l}\text { Wind direction at } \mathrm{Ob} \text { averaged } \\
\text { over 08:00-18:00 (UT) }\left(^{\circ}\right)\end{array}$ & 256 & 285 & 286 & 242 & 256 & 268 \\
\hline $\begin{array}{l}\text { Height of } Z i \text { at } \mathrm{Ob} \text { between } \\
11: 30 \text { and 13:30 (UT) (m) }\end{array}$ & 500 & 750 & 700 & 800 & 1100 & 1100 \\
\hline $\begin{array}{l}\text { Sensible heat flux at } 38 \mathrm{~m} \\
\text { height above ground at } \\
\text { CM averaged over } \\
\text { 11:30-13:30 (UT) }\left(\mathrm{W} \mathrm{m}^{-2}\right)\end{array}$ & 287 & 338 & 399 & 355 & 298 & 316 \\
\hline
\end{tabular}

LST and SST mean land and sea surface temperature, respectively.

global radiation is 968 and $922 \mathrm{~W} \mathrm{~m}^{-2}$, respectively. SST varies from 17.5 to $23.6{ }^{\circ} \mathrm{C}$ between 20 June and 29 June 2001. Table 3 presents also the time averaged value over the sea-breeze period (08:00-18:00 (UT)) of the local dynamical parameters (wind speed and direction) measured at $\mathrm{Ob}$. The surface wind is characterized by a weak velocity varying between 2 and $2.4 \mathrm{~m} \mathrm{~s}^{-1}$ from 1 day to another and a quite similar westerly direction. Wind velocity is maximum $\left(2.4 \mathrm{~m} \mathrm{~s}^{-1}\right)$ on 20 June and 29 June 2001 (without considering the cloudy day of 27 June 2001) when large horizontal land-sea temperature difference occurs (13.7 and $9.8{ }^{\circ} \mathrm{C}$, respectively). On the other days, horizontal temperature difference varies between 7.7 and $8.6^{\circ} \mathrm{C}$ and wind velocity is around $2.0-2.1 \mathrm{~m} \mathrm{~s}^{-1}$. The sensible heat flux values presented have been measured at $\mathrm{CM}$ and averaged over the 11:30-13:30 (UT) period. These values, function of the ground heating over Marseille city, vary between $287 \mathrm{~W} \mathrm{~m}^{-2}$ on 20 June 2001 and $399 \mathrm{~W} \mathrm{~m}^{-2}$ on 25 June 2001. The mixing height of the ABL observed by the UHF profiler at $\mathrm{Ob}$ around noon is also indicated in Table 3. ABL depth reaches up $500 \mathrm{~m}$ on 20 June 2001, 700-800 $\mathrm{m}$ on 24, 25 and 26 June 2001, and $1100 \mathrm{~m}$ on 27 and 29 June 2001.

\subsection{The sea-breeze on 25 June 2001}

In this section, the analysis of the meteorological conditions focused on 25 June 2001. The European Centre for Medium-Range Weather Forecasts (ECMWF) analysis on the $500 \mathrm{hPa}$ surface presented in Fig. 4 shows that, during that day, the ESCOMPTE domain was in the ridge of a high pressure system centered over northern Africa producing a 


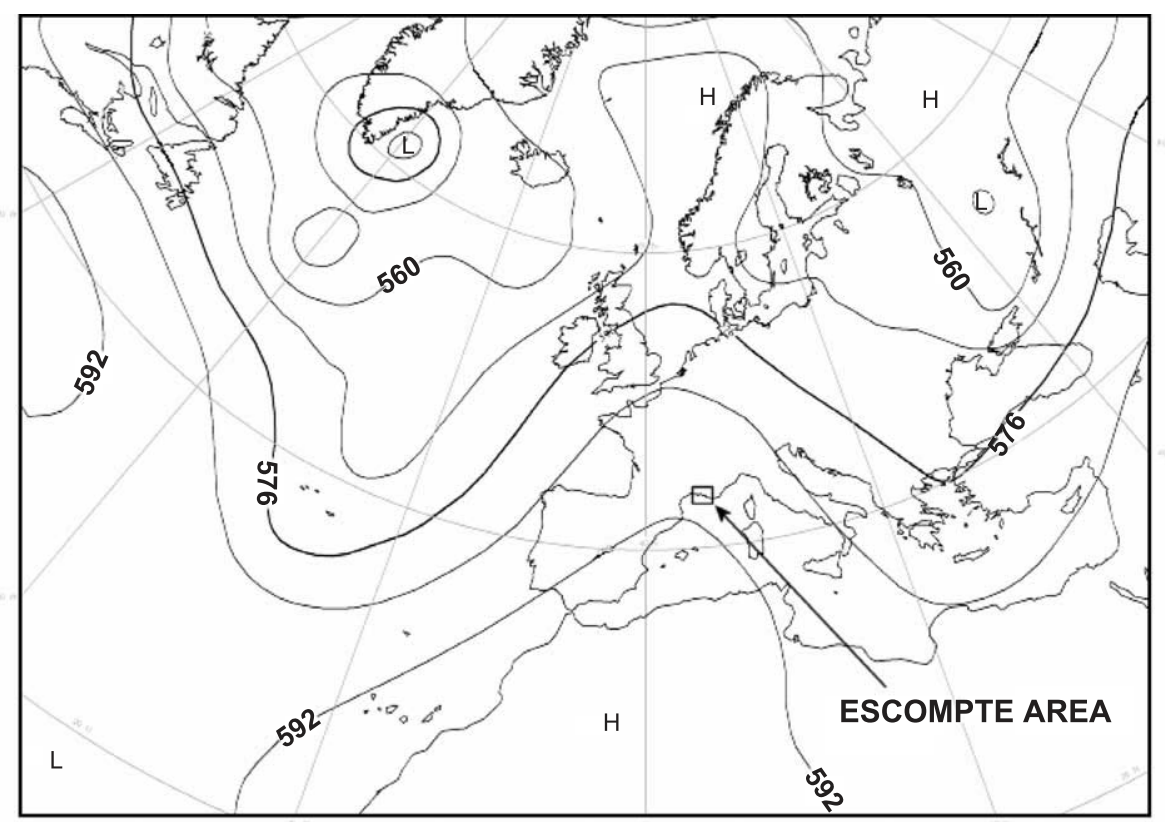

Fig. 4. Geopotential contours on the $500 \mathrm{hPa}$ surface on 25 June 2001 at 12:00 (UT) from ECMWF. The rectangle delineates the ESCOMPTE domain.

northwesterly flow of $13 \mathrm{~m} \mathrm{~s}^{-1}$ aloft. 25 June 2001 was a sunny day with scattered fair weather cumuli crossing the area, as can be deduced from the global radiation measured in $\mathrm{Ob}$ and SC shown in Fig. 5 (diagram a). This day was also characterized by strong sensible heat fluxes reaching about 500 and $300 \mathrm{~W} \mathrm{~m}^{-2}$ at the urban site $(\mathrm{CM})$ and the rural one (SC), respectively (cf. Fig. 5, diagram b). Land and sea-breeze daily evolution at SC are well documented both near the surface by the ground station and in the first $600 \mathrm{~m}$ of the ABL with the sodar (cf. Fig. 6). At this site, a weak northerly land-breeze blew until 06:00

(a)

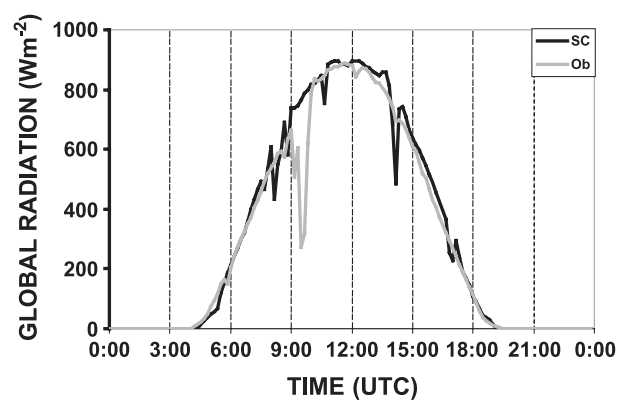

(b)

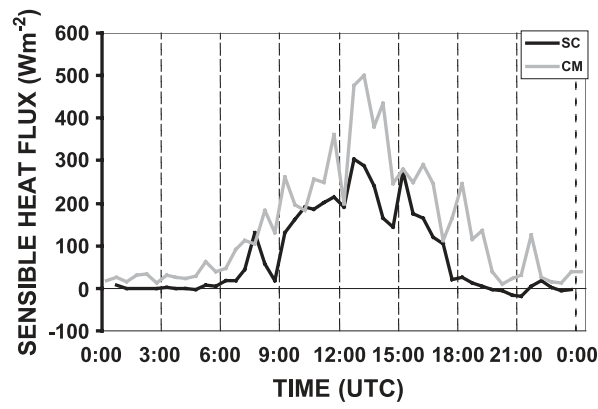

Fig. 5. Time series of: (a) global radiation and (b) sensible heat flux measured at SC (dark line) and Marseille (gray line) on 25 June 2001 (global radiation is measured at $\mathrm{Ob}$ and sensible heat flux at $\mathrm{CM}$ ). 
(a)

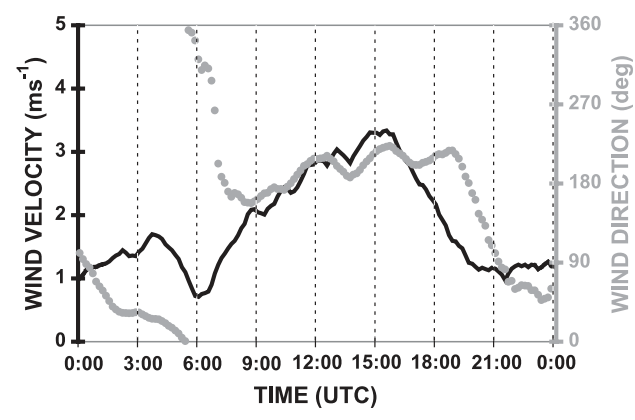

(b) WIND VELOCITY (ms-1)

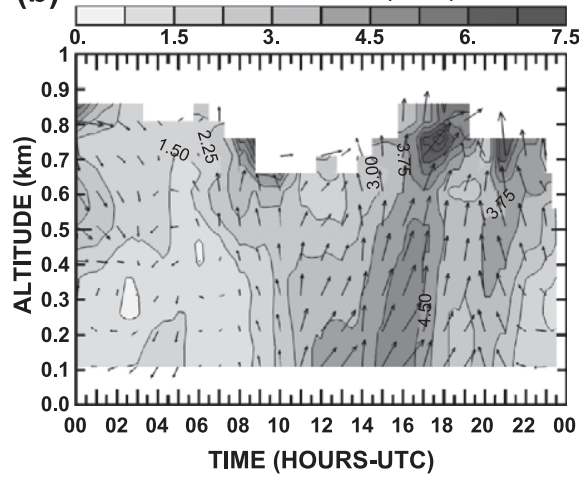

Fig. 6. (a) Time series obtained on 25 June 2001 of wind speed (black line) and direction (gray line) at the surface station at SC; (b) time-height cross-section of wind velocity (filled contours) and wind direction (arrows) measured by sodar at SC on 25 June 2001 ( 2 h average).

(UT), followed by a southerly sea-breeze until 20:00 (UT). Both sodar and ground station observed a land-breeze maximum (1.5-2 $\left.\mathrm{ms}^{-1}\right)$ around 04:00 (UT) and a sea-breeze maximum (3-5 $\mathrm{ms}^{-1}$ ) around 15:30 (UT).

The vertical development of convective ABL over homogeneous and flat continental areas depends essentially on the ground heating. All morning long, the air is warmed and homogenized by turbulent motions, which deepen the ABL height. In the early afternoon, the ABL stops its vertical development and stabilizes its height. Many works described this ABL behavior using tall masts and tethered balloons (Caughey and Kaimal, 1977), aircraft (Lenshow et al., 1980; Druilhet et al., 1983) or wind profilers (Weill et al., 1980; Angevine et al., 1994). In coastal environment, cool air advection associated to sea-breeze circulation limits such ABL vertical development. Because of the roughness and temperature changes between land and sea, the ABL depth increases with distance to the shoreline. $Z i$ rise depends on the wind speed, and on the characteristics of the marine air and land surface. The relative importance of both advection and turbulent mixing is function of the distance covered by the marine air advected above land surface (Raynor et al., 1979; Venkatram, 1986; Melas and Kambezidis, 1992). In order to determine the prevailing process, Wyngaard (1983) introduced a criterion between turbulence time-scale $\left(t_{\mathrm{t}}=Z i / W^{*}\right)$ and advection $\left(t_{\mathrm{a}}=x / u\right)($ Eq. $(1))$ :

$$
X m=\frac{t_{\mathrm{a}}}{t_{\mathrm{t}}}=\frac{x W^{*}}{u Z i}
$$

where $x$ is the upwind distance inland over which the air mass has traveled, $W^{*}$ is the convective velocity scale and $u$ is the mean wind speed in the ABL. Horizontal advection dominates for small $X m$, whereas the mixed layer is in local equilibrium and turbulence dominates for large Xm. Melas and Kambezidis (1992) suggest that the ABL is in local equilibrium for $X m$ higher than 5 and advection dominates entirely for $X m$ lower than 0.2. Between those two values, both mechanisms co-exist. 

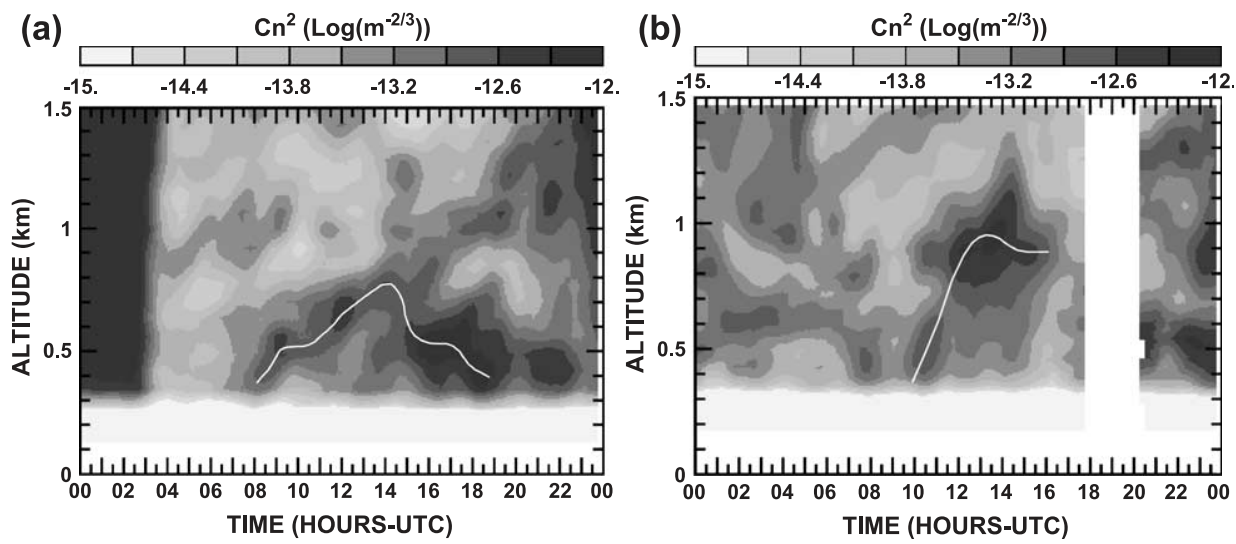

Fig. 7. Time-height cross-sections of $\mathrm{C}_{\mathrm{n}}^{2}$ measured on 25 June 2001 by UHF radar at $\mathrm{Ob}$ (a) and at Ax (b). On each diagram, the $A B L$ top is indicated with the white curve joining $C_{n}^{2}$ maxima.

ESCOMPTE campaign provides continuous temporal measurements of the ABL height at different distances to the coastline thanks to UHF wind-profilers observations. $\mathrm{Zi}$ behavior in ESCOMPTE area is illustrated in Fig. 7 by time-height cross-sections of the air refractive index structure constant $\mathrm{C}_{\mathrm{n}}^{2}$ measured at $\mathrm{Ob}$ and $\mathrm{Ax}$. $\mathrm{Zi}$ reaches up to $750 \mathrm{~m}$ and declines after 14:00 (UT) at $\mathrm{Ob}$ when the sea-breeze flow is maximum. Daytime evolution of $Z i$ at $\mathrm{Ob}$ is similar to the one studied by Steyn and Oke (1982) at two coastal sites. They observed that, during the morning development of the ABL, the turbulent motions dominate, whereas $Z i$ subsides when the marine advection increases later in the afternoon. On the other hand, the ABL depth reaches $1000 \mathrm{~m}$ and stabilizes in the afternoon at $\mathrm{Ax}$, the more distant UHF profiler site from the sea. Daytime evolution of $\mathrm{Zi}$ at $\mathrm{Ax}$ is quite similar to $\mathrm{ABL}$ continental case with a turbulent mixing predominance. Thus, marine air flow seems in thermal equilibrium before arriving at Ax. An estimation of Wyngaard's criterion with UHF radars gives $X m \sim 3.4$ and $X m \sim 16.2$ for the ABL observed at $\mathrm{Ob}$ and $\mathrm{Ax}$ at 12:30 (UT), respectively (calculated with the mean wind speed between $0.5 \mathrm{Zi}$ and $\mathrm{Zi}$ ). Although such a criterion is difficult to calculate accurately, this result confirms that both advection and turbulent mixing processes co-exist in the ABL development at $\mathrm{Ob}$, whereas the turbulent mixing has a major role at $\mathrm{Ax}$.

\section{Fine temporal structure of the sea-breeze}

In the previous section, the diurnal structure of the ABL has been depicted during the sea-breeze on 25 June 2001. In the present section, the inspection at a fine temporal scale of ground stations and wind profilers measurements for that day will put in evidence the existence of a sea-breeze flow oscillation. A detailed description of this phenomenon will be made above Marseille first. Next, the spatial extent of this process will be investigated over the whole ESCOMPTE area before analyzing, at last, the occurrence of pulsated seabreeze during the whole campaign. 


\subsection{Sea-breeze oscillation above Marseille on 25 June 2001}

Diagrams a-c on Fig. 8 show the westerly wind component time-height cross-sections produced by the UHF radar at $\mathrm{Ob}$ and the sodars at SJ and VD, respectively. Each crosssection includes the horizontal vector wind superimposed on the intensity of the westerly wind component (color scales) and the westerly wind component measured at the surface at the same location (black curve). The vertical coverage of these diagrams depends on the profiler type (cf. Table 2) and site altitude (cf. Table 1). UHF radar observations at Ob are not shown below $300 \mathrm{~m}$ because of the presence of strong ground echoes. For evident reason of noise disturbances, the sodar located at SJ in an urbanized zone did not work at night (17:00 until 07:00 (UT)). These figures display important variations of the westerly wind component $\left(2-3 \mathrm{~ms}^{-1}\right)$ with a $2.5-3 \mathrm{~h}$ period, at the surface as well as in the low ABL. This westerly wind component is the most relevant to highlight this oscillating structure. The comparison of Figs. 7 (diagram b) and 8 (diagrams a and c) shows that the height of the sea-breeze flow equals or exceeds the ABL depth; $Z i$ is 400, 700, 550 and 400 $\mathrm{m}$, while maxima of westerly wind velocity reach $400,700,800$ and $500 \mathrm{~m}$ at 09:00, 12:30,

(a)

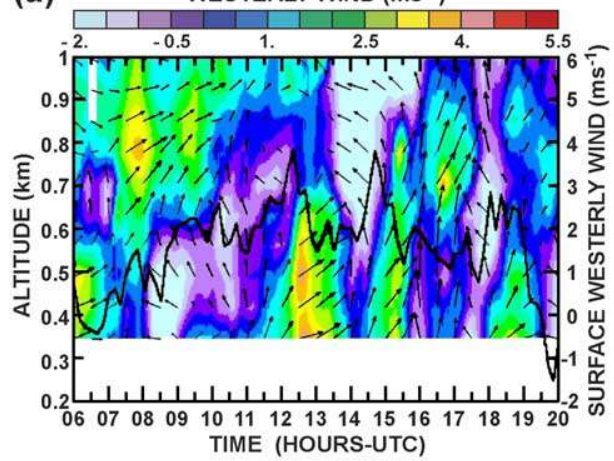

(c)

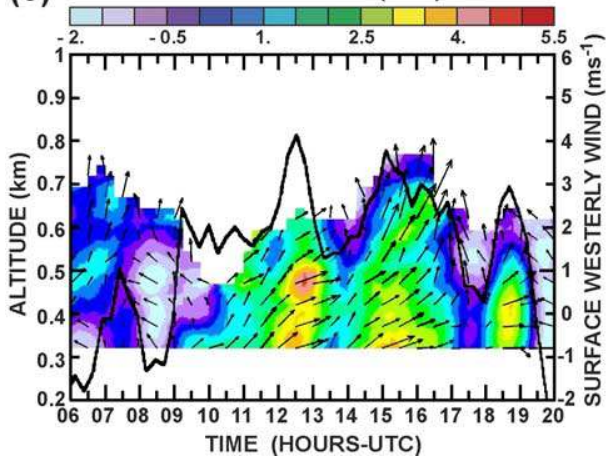

(b)

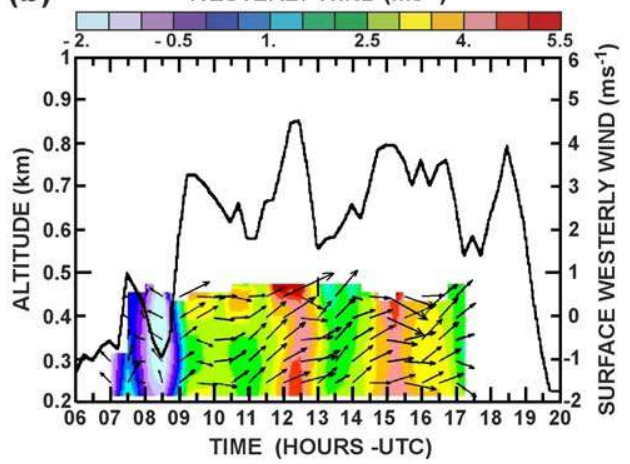

(d)

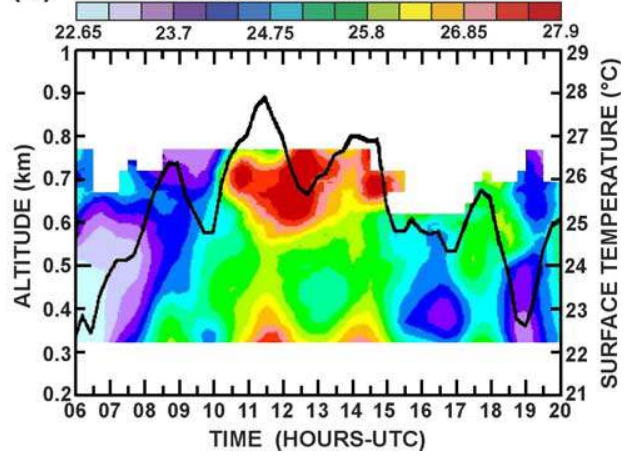

Fig. 8. Westerly wind component time-height cross-sections (color) measured on 25 June 2001 by UHF radar at $\mathrm{Ob}$ (a), sodar at SJ (b) and sodar at VD (c) (horizontal vectors wind measured by each profiler are superimposed). (d) Virtual temperature time-height cross-section measured on 25 June 2001 by the sodar-RASS at VD. Superimposed black curves represent surface westerly wind component $(a, b, c)$ or temperature (d). 
15:30 and 18:30 (UT), respectively. Fig. 8 (diagrams a-c) shows also that the turning of the wind due to Coriolis force throughout the day is not apparent in the observations. As Bastin et al. (2004) pointed out, this deviation to the standard description of the sea-breeze is due to the complexity of the area (ragged coastline, urban effect, topography).

Fig. 8 (diagram d) presents a time-height cross-section of the virtual temperature retrieved by the sodar-RASS and the temporal evolution of the surface temperature at VD. Oscillations of air temperature $\left(2-3{ }^{\circ} \mathrm{C}\right)$ with an identical period as the westerly wind oscillation are also observed at the surface and altitude. The air temperature oscillation affects the layer extending from the ground up to a $500 \mathrm{~m}$ height. In Fig. 8, air temperature and westerly wind component appear anti-correlated.

Fig. 9 (diagram a) clearly illustrates the anti-correlation between temperature and westerly wind component with ground station measurements at $\mathrm{Ob}$. This phenomenon can be explained by the different residential time of the advected marine air above the city. A weak sea-breeze flow has more time to be warmed up during its transit over the city than a stronger one. This hypothesis seems corroborated by the observations of the ground stations S1-S20 (see their location in Fig. 1, diagram b). Fig. 9 (diagram b) shows air

(a)

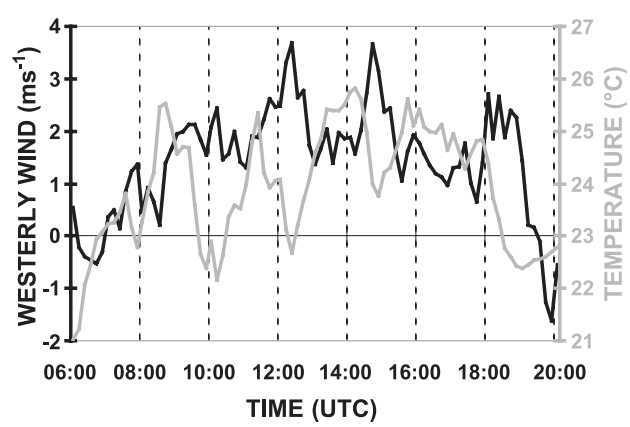

(b)

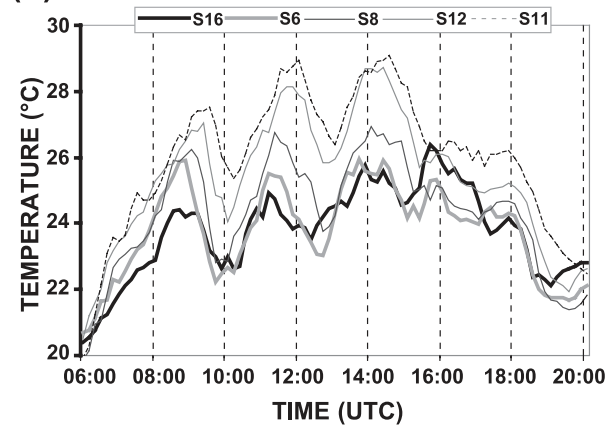

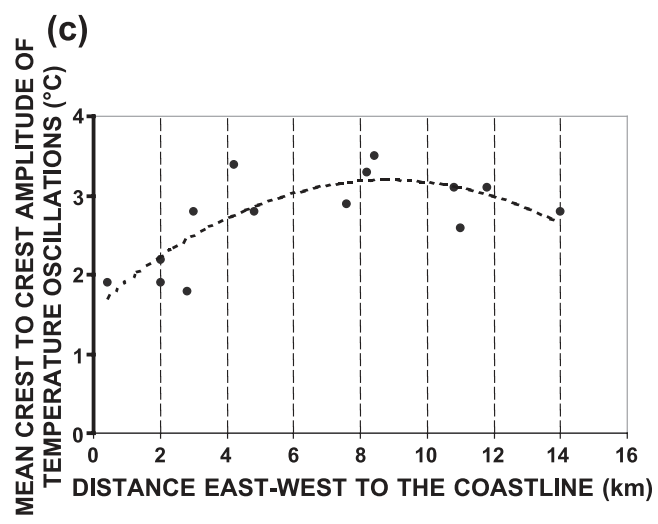

Fig. 9. Time series of: (a) air surface temperature and westerly wind component at $\mathrm{Ob}$; (b) air surface temperature at S16, S6, S8, S12, S11 (both measured on 25 June 2001 between 06:00 and 20:00 (UT)). (c) Mean crest to crest amplitude of the surface temperature variations according to the east-west distance to the coastline calculated on 25 June 2001 daytime. The dashed curve is a second degree polynomial fit. 
temperature measured at ground stations S16, S6, S8, S12 and S11. These stations are line up on a southwest to northeast axis direction $\left(240^{\circ}\right)$, which makes an angle of $46^{\circ}$ from the mean wind direction at $\mathrm{Ob}\left(286^{\circ}\right)$ between 06:00 and 18:00 (UT) (cf. Table 3).

The signature of the sea-breeze horizontal propagation can be deduced from the delay in the observation of the temperature maxima (or minima) in the different sites. Between $\mathrm{S} 16$ and S11, we obtain a propagation velocity about $4 \mathrm{~m} \mathrm{~s}^{-1}$, which is similar to the seabreeze mean wind magnitude. For 14 ground stations of the network, the mean crest to crest amplitude of the temperature fluctuations was calculated from the time series. Fig. 9 (diagram c) presents these mean amplitudes according to the east-west distance to the coastline. This curve is fitted with a second degree polynomial function. The distance effectively covered by the marine air over land can not be calculated, because wind measurements were not available at stations S1-S20 (cf. Section 2.1). An approximation is made by using the east-west distance to the coastline since the mean wind direction is roughly westerly $\left(286^{\circ}\right.$ at $\left.\mathrm{Ob}\right)$. This figure shows that the temperature fluctuation amplitude increases with the east-west distance from the coastline up to 8-9 km, followed by a slow drop beyond $8 \mathrm{~km}$. This phenomenon can also be explained by the warming rate of the marine air during its transit above the land surface. A short distance does not let enough time for the marine air to warm up, whereas a too long one enables the marine air to reach the thermal equilibrium with the land surface.

To quantify the periodicity of sea-breeze flow oscillations previously described, a spectral analysis method was used. This method has been utilized because an objective criterion is needed to study the horizontal spatial extent of the flow oscillation in the next section, notably to estimate the power spectral density of the different harmonics. Fig. 10 presents the results of the Fourier analysis made on surface air temperature and westerly wind component time series with 5 min sampling obtained at VD on 25 June 2001 between 06:00 and 20:00 (UT). Three peaks are identifiable in this analysis; the DC line (harmonic 0) is related to the synoptic forcing, the $13 \mathrm{~h} 59 \mathrm{~min}$ period is related to the diurnal cycle (mesoscale) of the sea-breeze and a $2 \mathrm{~h} 47 \mathrm{~min}$ period is considered as the

(a)

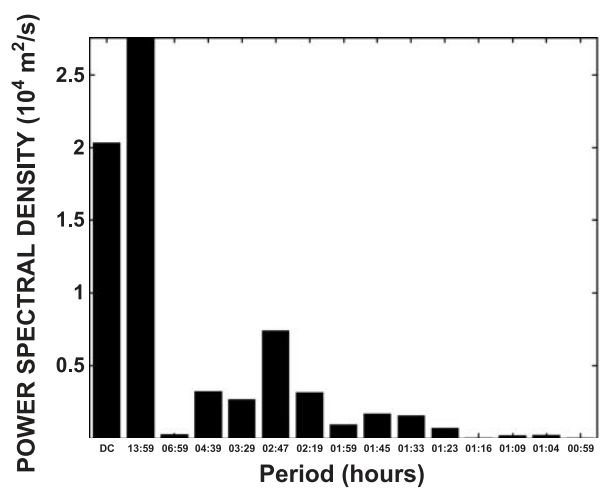

(b)

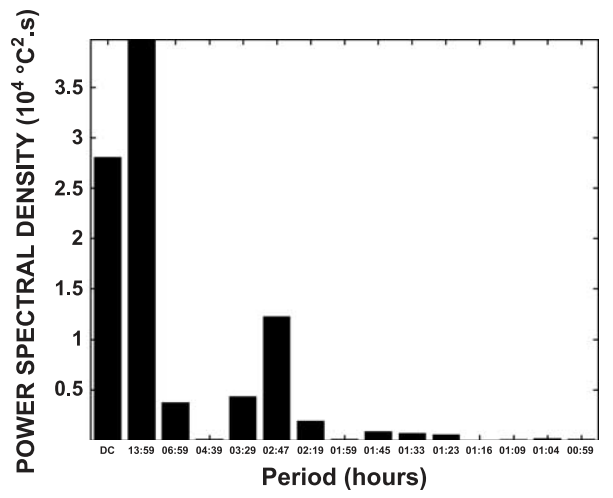

Fig. 10. Power spectral density of the surface westerly wind component (a) and surface air temperature (b) measured at VD on 25 June 2001 between 06:00 and 20:00 (UT) (DC is the harmonic 0 and other periods are indicated in hours, for example 13:59 means $13 \mathrm{~h}$ and $59 \mathrm{~min}$ ). 
period of the pulsated sea-breeze. Fourier analysis can introduce various artifacts for discrete time series with small numbers of cycles. In the present case, the Fourier analysis reveals a $2 \mathrm{~h} 47$ min period clearly identifiable for both parameters corresponding to the period previously put in evidence in Fig. 9 (diagram a).

In summary, a sea-breeze flow oscillation with a $2 \mathrm{~h} 47 \mathrm{~min}$ period affects the $0-800 \mathrm{~m}$ layer of the atmosphere above Marseille. Wind velocity variations change the warming time rate of the advected marine air, and thus air temperature above the whole city. However, only dynamical parameters will be used in the following section to study the horizontal extent of this phenomenon because the temperature oscillation signature is dependent on the distance covered over land by the marine air.

\subsection{Horizontal domain of the pulsated sea-breeze on 25 June 2001}

Is the phenomenon of pulsated sea-breeze confined over Marseille city or does it affect other parts of the domain? To answer this question, a similar Fourier analysis has been applied to daytime surface southerly and westerly wind components collected at LC, LB, $\mathrm{Du}, \mathrm{Re}, \mathrm{VD}, \mathrm{Ob}$ and SC (cf. Fig. 1 (diagram a) and Table 1). This analysis gives the averaged energy value of the two highest harmonics among the $2 \mathrm{~h} 30 \mathrm{~min}, 2 \mathrm{~h} 47 \mathrm{~min}$ and $3 \mathrm{~h} 10$ min periods at each selected site. This value is then normalized by the energy of the whole spectrum. In order to simplify both parameters and sites comparisons, all normalized energies are expressed in percentage of the normalized SC westerly wind energy, whose magnitude is the highest one (cf. Fig. 11). An important difference can be noted between the two wind components since the southerly wind component energies around $2 \mathrm{~h} 47 \mathrm{~min}$ are lower than the westerly component (less than $30 \%$ of the westerly component at SC). In Fig. 11, the dark gray color indicates when a maximum is observed on one of the three harmonics ( $2 \mathrm{~h} 30 \mathrm{~min}, 2 \mathrm{~h} 47 \mathrm{~min}$ and $3 \mathrm{~h} 10 \mathrm{~min}$ ) among all harmonics between 1 and $6 \mathrm{~h}$. Thus, an oscillation with a $2 \mathrm{~h} 47 \mathrm{~min}$ period is only observed on the westerly wind component in SC (100\%), Ob (60\%), VD (65\%) and Re

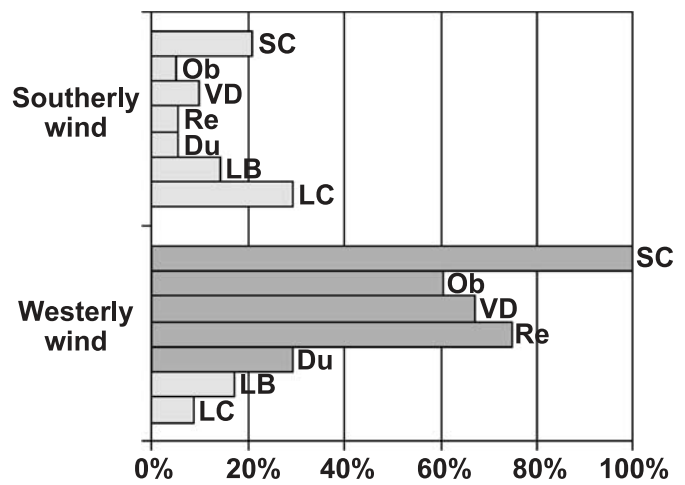

Fig. 11. Mean energy of the two most energetic harmonics among $2 \mathrm{~h} 30 \mathrm{~min}, 2 \mathrm{~h} 47 \mathrm{~min}$ and $3 \mathrm{~h} 10 \mathrm{~min}$, normalized by the whole spectrum energy of westerly and southerly wind components at SC, Ob, VD, Re, Du, LB and LC (all expressed in percentage of the SC westerly wind component harmonic) (see text for more explanation). Dark gray color indicates the harmonic when a maximum is observed on one of the $2 \mathrm{~h} 30 \mathrm{~min}, 2 \mathrm{~h}$ $47 \mathrm{~min}, 3 \mathrm{~h} 10 \mathrm{~min}$ harmonics. 
(75\%) and to a lesser extent in $\mathrm{Du}(30 \%)$. Whatever the site, the southerly wind component does not exhibit any $2 \mathrm{~h} 47 \mathrm{~min}$ period oscillation.

Finally, based on all these elements, we can conclude that the periodic behavior of the sea-breeze observed above Marseille is also manifested over the northern and eastern shores of Berre pond.

\subsection{Analysis of other sea-breeze days}

Six days with breeze circulations have been analyzed. Their synoptic and local meteorological conditions have already been presented in Section 3 (cf. Table 3). SodarRASS at VD was considered the most relevant to detect oscillations of wind speed and virtual temperature. Time series have been analyzed between 06:00 and 20:00 (UT) and at a $350 \mathrm{~m}$ height. The vertical extension of the pulsated sea-breeze and Wyngaard's criterion $X m$ was determined with the UHF radar measurements at $\mathrm{Ob}$. The results are shown in Table 4.

Among the 6 days analyzed, three are characterized by air temperature and westerly wind component oscillations: 20, 25 and 26 June 2001. Although the periodicity of this phenomenon is nearly similar for the 3 days $(2 \mathrm{~h} 00 \mathrm{~min}-2 \mathrm{~h} 45 \mathrm{~min})$, the pulsated seabreeze intensity on 20 and 26 June 2001 is weaker than on 25 June 2001. The mean magnitude of the westerly wind component oscillation is 2.2 and $1.9 \mathrm{~m} \mathrm{~s}^{-1}$ on 20 and 26 June 2001, respectively, against $3.1 \mathrm{~m} \mathrm{~s}^{-1}$ on 25 June 2001. The same goes for the temperature oscillation magnitude, which is about 0.9 and $1.1{ }^{\circ} \mathrm{C}$ on 20 and 26 June 2001 , respectively, against $1.9{ }^{\circ} \mathrm{C}$ on 25 June 2001. Additionally, a good correlation exists between the oscillation amplitude of both variables, i.e. when the wind variation magnitude is high the temperature variation is important. The vertical extension of the

Table 4

Parameters characterizing the pulsated sea-breeze for 6 sea-breeze days obtained with sodar at VD or UHF radar at $\mathrm{Ob}$ (indicated on each lines of the table by [VD] and [Ob], respectively)

\begin{tabular}{|c|c|c|c|c|c|c|}
\hline & $\begin{array}{l}20 \text { June } \\
2001\end{array}$ & $\begin{array}{l}24 \text { June } \\
2001\end{array}$ & $\begin{array}{l}25 \text { June } \\
2001\end{array}$ & $\begin{array}{l}26 \text { June } \\
2001\end{array}$ & $\begin{array}{l}27 \text { June } \\
2001\end{array}$ & $\begin{array}{l}29 \text { June } \\
2001\end{array}$ \\
\hline Pulsated sea-breeze [VD] & Yes & No & Yes & Yes & No & No \\
\hline $\begin{array}{l}\text { Period of temperature and } \\
\text { westerly wind component } \\
\text { oscillation (h) }[\mathrm{VD}]\end{array}$ & $\sim 2 \mathrm{~h}$ & & $\sim 2 \mathrm{~h} 45 \mathrm{~min}$ & $\sim 30 \mathrm{~min}$ & & \\
\hline $\begin{array}{l}\text { Mean crest to crest } \\
\text { amplitude of westerly wind } \\
\text { component oscillations } \\
\left(\mathrm{m} \mathrm{s}^{-1}\right)[\mathrm{VD}]\end{array}$ & 2.2 & & 3.1 & 1.9 & & \\
\hline $\begin{array}{l}\text { Mean crest to crest } \\
\text { amplitude of temperature } \\
\text { oscillations }\left({ }^{\circ} \mathrm{C}\right)[\mathrm{VD}]\end{array}$ & 0.9 & & 1.9 & 1.1 & & \\
\hline $\begin{array}{l}\text { Maximum height of } \\
\text { extension }(\mathrm{m})[\mathrm{Ob}]\end{array}$ & 500 & & 800 & 300 & & \\
\hline $\begin{array}{l}\text { Wyngaard 's criterion } \\
(\mathrm{Xm})[\mathrm{Ob}]\end{array}$ & 4.1 & 3.4 & 4.2 & 3.8 & 2.4 & 2.5 \\
\hline
\end{tabular}


pulsated sea-breeze is the deepest on 25 June 2001 (800 m). On 20 and 26 June 2001, the ABL is only affected up to 500 and $300 \mathrm{~m}$ high, respectively. Wyngaard's criterion Xm shows that turbulence and advection are both present each day since $X m$ values vary between 2.4 and 4.2. Days with pulsated sea-breeze exhibit the highest values of Xm (3.8, 4.1 and 4.2). However, this conclusion is not totally reliable because of the important inaccuracy in the calculation of $X m$ as discussed in a previous section.

None of the synoptic and local parameters individually taken can be clearly related to the presence of a pulsated sea-breeze. Only Wyngaard's criterion, which combines several ABL characteristics, allows to distinguish a weak signature for its presence. However, this observation is based on six cases and does not constitute a significant statistical sample to infer any general law. An experimental approach can not explain alone the reason why pulsated sea-breezes occurred in half of the studied cases. A numerical study should be undertaken to confirm this conclusion or to explore other possibilities.

\section{Consequence of the pulsated sea-breeze}

Sea-breeze effects on coastal low troposphere and notably on Marseille ABL are now investigated still focusing on 25 June 2001. As shown in previous section, a sea-breeze flow oscillation modifies the residential time of the marine air above Marseille. Considering the stable temperature profile above the sea, the ABL stability conditions should be strongly affected by this sea-breeze behavior, implying successive modifications on the convection and turbulent characteristics. The impact of marine air advection is also studied through the temporal analysis of different trace gas concentrations.

\subsection{Stability and turbulence characteristics within Marseille ABL}

Fig. 12 (diagram a) presents a vertical sounding performed by Météo France instrumented aircraft Merlin IV over the sea at 15:00 (UT), between 0 and $3000 \mathrm{~m}$. A stable potential temperature vertical profile is observed with a $12{ }^{\circ} \mathrm{C}$ increase within the first kilometer of the atmosphere. The thermal equilibrium of the stable marine air above Marseille heated surface depends on the horizontal advection intensity.

The time-height cross-section of uncalibrated temperature structure constant $\left(\mathrm{C}_{\mathrm{T}}^{2}\right)$ measured by the sodar at $\mathrm{SJ}$ is presented in Fig. 12 (diagram b). $\mathrm{C}_{\mathrm{T}}^{2}$ corresponds to temperature fluctuations linked to processes whose characteristic scales are in the inertial subrange; high $\mathrm{C}_{\mathrm{T}}^{2}$ values are associated with strong turbulent activity, which tends to homogenize the temperature profile. $\mathrm{C}_{\mathrm{T}}^{2}$ maxima are observed at 10:30, 12:30 and 15:00 (UT) at about $300 \mathrm{~m}$ height. Hatched areas indicate intensifications of the westerly wind component measured by this sodar. $\mathrm{C}_{\mathrm{T}}^{2}$ maxima at $300 \mathrm{~m}$ occur when sea-breeze flow intensifies, or in other words, when marine air has less time to equilibrate with continental warm surface.

Study of upper ABL vertical structure (from 400 up to $1100 \mathrm{~m}$ ) can be made with UHF radar $C_{n}^{2}$ measurements (cf. Fig. 12, diagram c). The local maxima of $C_{n}^{2}$ is located at the mixing height $Z i$ as explained in Section 3. $Z i$ increases discontinuously from $400 \mathrm{~m}$ at 08:30 up to $750 \mathrm{~m}$ at 14:30 (UT) since three successive $C_{n}^{2}$ maxima can be observed at 
(a)

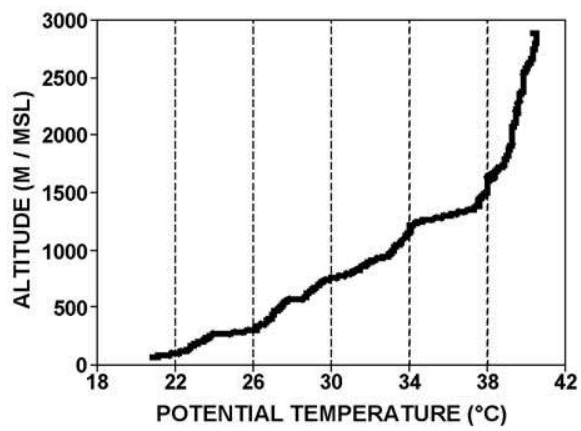

(c)

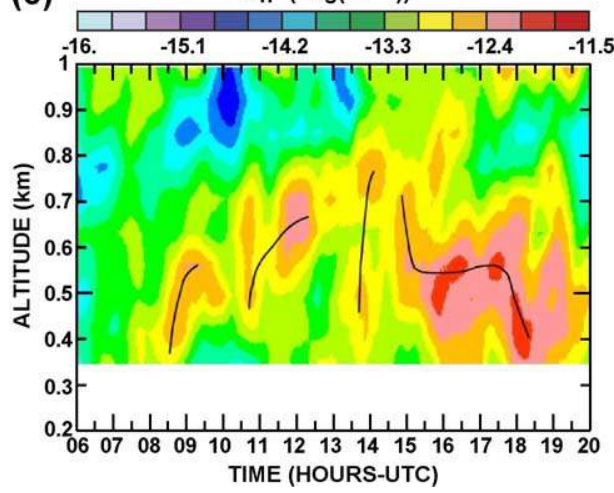

(b) UNCALIBRATED $\mathrm{C}_{\mathrm{T}}^{2}\left(100 \mathrm{~K}^{2} \mathrm{~m}^{-2 / 3}\right)$

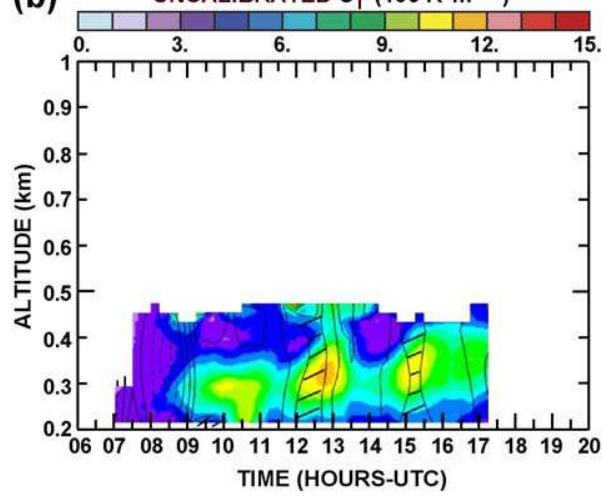

(d)
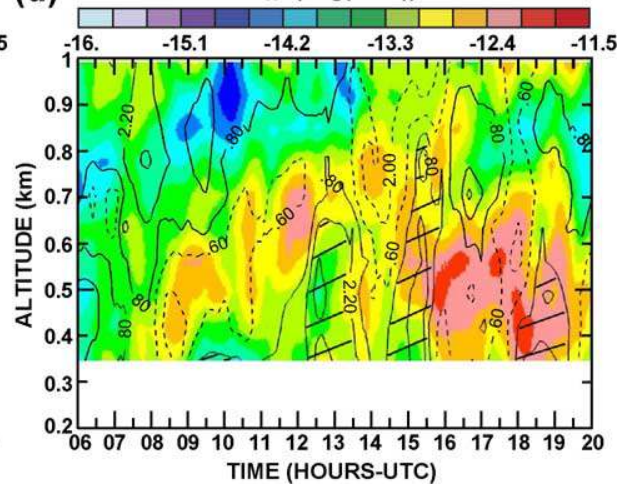

Fig. 12. (a) Profile of potential temperature measured above the sea by the instrumented aircraft Merlin IV at 15:00 (UT) on 25 June 2001; (b) uncalibrated $\mathrm{C}_{\mathrm{T}}^{2}$ time-height cross-section measured by sodar at SJ on 25 June 2001; (c) and (d): $\mathrm{C}_{\mathrm{n}}^{2}$ time-height cross-section measured by UHF radar on 25 June 2001 at Ob (superimposed black curves indicate $C_{n}^{2}$ maxima on (c) and black isolines indicate westerly wind component on (d)). Hatched areas indicate maxima of the westerly wind component on (b) and (d).

08:00-09:30, 11:00-12:30 and 13:30-14:30 (UT). Between these maxima, $\mathrm{C}_{\mathrm{n}}^{2}$ values decrease significantly. $A \mathrm{C}_{\mathrm{n}}^{2}$ time-height cross-section with westerly wind contours is also presented on Fig. 12 (diagram d). Hatched areas represent intensifications of westerly wind component measured by the UHF radar. This figure shows that $\mathrm{C}_{\mathrm{n}}^{2}$ drops at $\mathrm{ABL}$ top occur when sea-breeze flow intensifies.

The physical meaning of these sodar and radar observations is that a higher/lower ABL top is observed for a low/high sea-breeze flow. The stable potential temperature profile observed over the sea has more or less time to be homogenized over the land surface. For a weak advection of marine air, the ABL top is defined through the $C_{n}^{2}$ since the $C_{T}^{2}$ is low and homogeneous in the first $500 \mathrm{~m}$ of the atmosphere. For a strong advection of marine air, the ABL top is defined through the $C_{T}^{2}$ since the $C_{n}^{2}$ values drop at the previous levels. This observation might be the consequence of the stabilization of the air and the reduction of the turbulence above this very thin ABL. 
$Z i$ falls after 15:00 (UT) during the third sea-breeze flow intensification. Compared to the value observed at 12:00 (UT), the sensible heat flux over Marseille at 15:00 (UT) has already been divided by two (cf. Fig. 5, diagram b) and is not sufficiently strong to regenerate a new boundary layer.

The pulsated sea-breeze has important impacts on the ABL stability and its turbulent motions. The successive reductions and increases of the ABL depth can be related to the convection through the vertical velocity. Fig. 13 presents the temporal evolution of westerly wind component and vertical velocity measured by UHF radar at $350 \mathrm{~m}$ (at $\mathrm{Ob}$ ) between 07:00 and 19:00 (UT). Before going on, it is important to notice that vertical wind measurements with UHF profilers present a negative bias (usually lower than $0.1 \mathrm{~m} \mathrm{~s}^{-1}$ in absolute value) that is well known but not explained yet (Angevine, 1997; Lothon et al., 2002). However, only the relative fluctuations of the vertical velocity and their correlation to the sea-breeze oscillations are considered here. At $350 \mathrm{~m}$, the UHF radar detects the seabreeze flow intensifications at around 10:00, 12:45, 15:15 and 18:30 (UT). Vertical velocity maxima are perfectly correlated with westerly wind ones before 08:00 and after 16:00 (UT). During most of the sea-breeze period (08:00-16:00 (UT)), vertical velocity displays a phase shift with westerly wind component (nearly anti-correlated). The vertical velocity maxima can be observed at $08: 45,12: 15$ and 14:15 (UT). In order to evaluate this phase shift, cross-correlation of those two parameters have been done. The result shows that vertical velocity maxima occurred $50 \mathrm{~min}$ in average before westerly wind component maxima. A similar phase difference is found between the two wind components up to $650 \mathrm{~m}$ height. Above this level, these two parameters are well correlated.

The above description allows us to propose a possible explanation on the atmospheric process that could explain this pulsated sea-breeze. When the sea-breeze intensity decreases, much more solar energy is transferred to turbulent vertical transport. Then, the turbulent mixing takes an increasing role in the ABL development implying an increase of $Z i$ and vertical convection. Maxima of vertical velocity are then observed. Due to the mass transfer aloft, the low pressure over land is accentuated what increases the horizontal pressure gradient and amplifies the sea-breeze flow. Then, stable marine air is advected

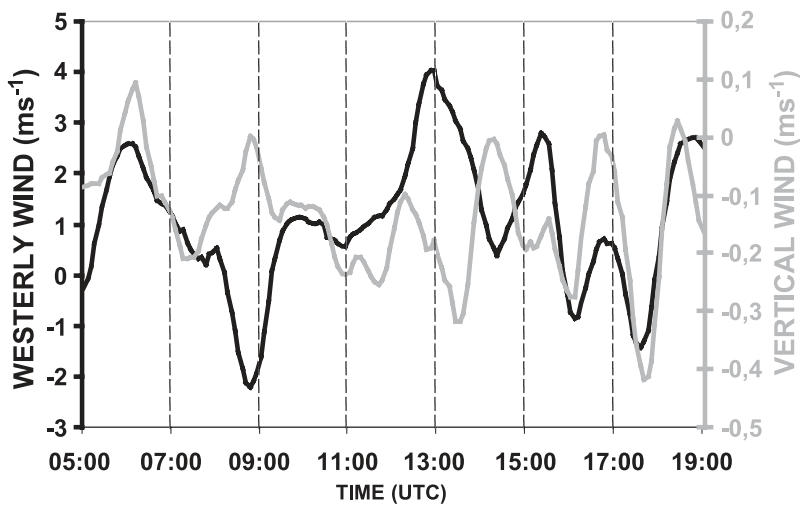

Fig. 13. Temporal evolution of the vertical velocity and the westerly wind component measured by UHF radar at Ob on 25 June 2001 at $350 \mathrm{~m}$ between 06:00 and 19:00 (UT) (the mean value have been removed). 
with a stable temperature profile leading to a convection break down above the land. Several hours are necessary to homogenize again the air and restart the convection. This hypothesis should be confirmed by a numerical approach to test different geographical, dynamical or thermal parameters, and quantify their respective role. The geographical situation should be particularly investigated to study the influences of slope wind processes and the particular role of urbanized areas.

\subsection{Pollution in the Marseille ABL}

Fig. 14 (diagram a) presents nitrogen dioxide $\left(\mathrm{NO}_{2}\right)$ and ozone $\left(\mathrm{O}_{3}\right)$ concentrations measured in the afternoon (16:26-17:10 (UT)) at the end of the Bastia-Marseille ferry crossing, the route of which is indicated in Fig. 1 (diagram b). Fig. 14 (diagram a) shows that the marine air is poorer in $\mathrm{NO}_{2}$ and richer in $\mathrm{O}_{3}$ than the air near the coastline at Marseille; 2-3 and 50-60 ppb are observed over the sea against $12-15$ and 30-40 ppb at the shoreline, for $\mathrm{NO}_{2}$ and $\mathrm{O}_{3}$ concentrations, respectively.

Fig. 14 (diagram b) presents $\mathrm{NO}_{2}$ and $\mathrm{O}_{3}$ concentrations measured at $\mathrm{Ob}$ between 09:00 and 19:00 (UT) by the air quality network AIRMARAIX. The early morning is not presented on this figure to disregard the large peak of $\mathrm{NO}_{2}$ caused by the road traffic emission (Cousin et al., 2004). This figure shows that $\mathrm{NO}_{2}$ concentration falls periodically from $30-35$ to $15-20 \mathrm{ppb}$ simultaneously to the maxima of the sea-breeze intensity (indicated on Fig. 14 (diagram $b$ ) with the black arrows) at 12:15-12:30, 14:00-15:00 and 18:00-18:30 (UT). Each decrease of $\mathrm{NO}_{2}$ concentration is followed by a slow increase back to the anterior value. $\mathrm{O}_{3}$ concentration is nearly constant $(30-40 \mathrm{ppb})$ during the day and periodic falls to $20-25 \mathrm{ppb}$, which are followed by a rapid increase back to the higher value, are observed simultaneously with $\mathrm{NO}_{2}$ concentration minima.

Urban zones are mainly responsible for the emission of $\mathrm{NO}$ (quickly oxidized into $\mathrm{NO}_{2}$ during daytime) and consequently marine air is necessarily poorer in $\mathrm{NO}_{2}$ than urban one. $\mathrm{NO}_{2}$ concentration of the marine air increases as this air travels over Marseille in function of its residential time over the urban surface. $\mathrm{NO}_{2}$ concentration observed at $\mathrm{Ob}$ is then higher for a slow sea-breeze flow and lower for a strong one. If the residential time over

(a)

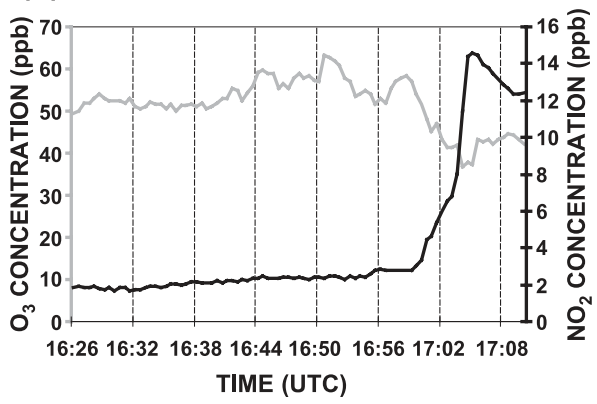

(b)

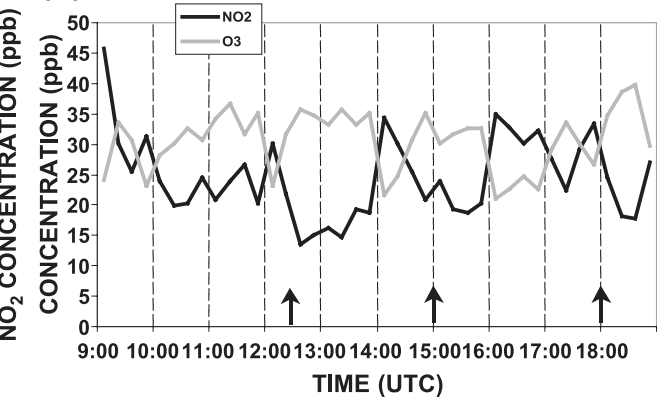

Fig. 14. The nitrogen dioxide $\left(\mathrm{NO}_{2}\right)$ and ozone $\left(\mathrm{O}_{3}\right)$ concentrations measured on 25 June 2001: (a) with BastiaMarseille Ferry from 16:26 to 17:10 (UT) and (b) at Ob from 09:00 to 19:00 (UT) (black arrows indicate westerly wind maxima). 
the city is too long, the $\mathrm{NO}_{2}$ concentration becomes excessive and shifts the $\mathrm{O}_{3}$ photochemical equilibrium towards the VOC-limited regime, which decreases instantaneously $\mathrm{O}_{3}$ concentration as observed at $\mathrm{Ob}$ before a maximum of the sea-breeze flow.

Thus, the pulsated sea-breeze has an important impact on Marseille air quality since it prevents the $\mathrm{NO}_{2}$ concentration to reach higher values and the $\mathrm{O}_{3}$ concentration to reach lower ones.

\section{Conclusion}

During the ESCOMPTE campaign, a wide range of instruments (notably remote sensing, in situ and aircraft measurements) was put in operation in the Marseille region. Those instruments allowed a continuous documentation at a fine temporal and vertical resolution of the ABL and sea-breeze flows. Six days with sea-breeze circulations were analyzed. Three of them present oscillations of the sea-breeze flow. This pulsated behavior was investigated with a detailed study of 25 June 2001 using profilers (UHF radar, sodar and RASS) and meteorological ground stations disposed in urban or rural sites in the coastal zone. The main characteristics of this pulsated sea-breeze are summed up below:

- A 2 h $47 \mathrm{~min}$ period oscillation of the sea-breeze intensity (around 2-3 $\mathrm{ms}^{-1}$ )

- A depth equal or higher than the height of the ABL

- A presence detected at Marseille and at the northern and eastern shores of the Berre pond.

The study of the ABL above Marseille on 25 June 2001 shows that the stability and convection motions are modified by the periodic advection of stable marine air. These $\mathrm{ABL}$ characteristics are deduced from physical interpretation of the temporal and vertical continuous wind profilers measurements. Fig. 15 is a schematic illustration of the ABL over Marseille during three stages of the sea-breeze flow oscillation. During stage 1, wind

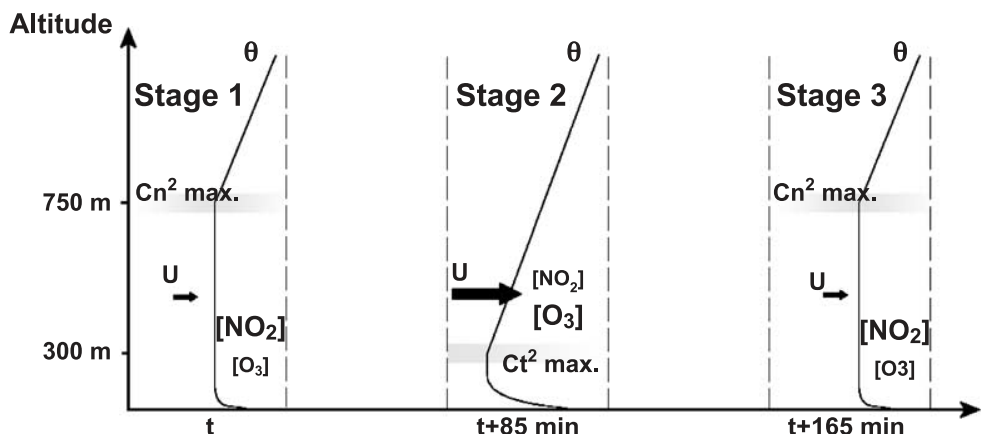

Fig. 15. Schematic time-height diagram of the ABL evolution during one period of the pulsated sea-breeze. Three stages indicate the vertical profile of potential temperature $(\theta)$, the $C_{n}^{2}$ and $C_{T}^{2}$ maxima (gray areas) from measurements of UHF radar and sodar, the velocity of the sea-breeze with an arrow (whose size is proportional to the wind intensity), and the nitrogen dioxide $\left(\mathrm{NO}_{2}\right)$ and ozone $\left(\mathrm{O}_{3}\right)$ concentrations (whose label size is proportional to the concentration). 
speed is low giving enough time to the stable potential temperature profile being deeply homogenized over the continental surface and to the air being $\mathrm{NO}_{2}$ laden. The UHF wind profiler detects a maximum ABL mixing height of about $750 \mathrm{~m}$. The excess of $\mathrm{NO}_{2}$ contributes to the destruction of $\mathrm{O}_{3}$, the concentration of which decreases. Next, the seabreeze intensity increases progressively and becomes maximum in stage 2 . The advected marine air has less and less time to equilibrate with the land surface and to load in $\mathrm{NO}_{2}$. The ABL becomes thinner and is overlaid by a deep stable layer. At this stage, the sodar detects a maximum of $\mathrm{C}_{\mathrm{T}}^{2}$ in the lower part of the ABL (at about $300 \mathrm{~m}$ ). The ABL characteristics will progressively evolve again as the sea-breeze intensity decreases. The turbulent mixing gets more and more efficient for the ABL vertical development, which returns to the same configuration as stage 1 (stage 3 ). This periodic oscillation of the seabreeze could indefinitely continue if sensible heat fluxes did not drop in the afternoon.

The analysis of the temporal oscillations of the vertical wind component measured by the UHF wind profiler suggests a possible explanation for the pulsated sea-breeze. Turbulent mixing efficiency increases the ABL depth and the vertical transport, generating an increase of the depression of the low ABL and a rise of the sea-breeze flow intensity. This induced intensification of the sea-breeze flow stabilizes the air, decreases the turbulent mixing and the $\mathrm{ABL}$ depth. The vertical transport is then reduced which contributes to diminish the depression and the sea-breeze intensity.

Numerical simulations should be undertaken both to have a complete description of the impacts of the pulsated sea-breeze and to study the sources of this process. They should determine the respective role of several parameters as topography, complexity of the shoreline and urban heat island effect.

\section{Acknowledgements}

ESCOMPTE experiment was funded by the French programs PNCA and PRIMEQUAL. Partner organisms were the Ministère de l'écologie et du développement durable (MEDD), the Institut National des sciences de l'Univers (INSU), the Agence de l'Environnement et de la Maîtrise de l'Energie (ADEME), Météo-France, the Centre National d'Etudes Spatiales (CNES), the air quality agencies AIRMARAIX and AIRFOBEP. The authors would like to thank the Centre National de Recherches Météorologiques, Electricite De France, the Laboratoire des Sondages Electromagnétiques de l'Environnement Terrestre, the Ecole Centrale de Nantes, the Indiana University for providing data used in this work, and B. Cros and P. Durand for the coordination of the experiment.

\section{References}

Angevine, W.M., 1997. Errors in mean vertical velocities measured by boundary layer wind profilers. J. Atmos. Ocean. Technol. 14, 565-569.

Angevine, W.M., White, A.B., Avery, S.K., 1994. Boundary-layer depth and entrainment zone characterization with boundary-layer profiler. Boundary-Layer Meteorol. 68, 375-385.

Bastin, S., Drobinski, P., Delville, P., Reitebuch, O., Werner, C., 2004. Impact of the Rhône and Durance valleys on sea-breeze circulation in the Marseille area. Atmos. Res. 74, 303-328 (this issue). 
Batchvarova, E., Cai, X., Gryning, S.E., Steyn, D., 1999. Modelling internal boundary-layer development in a region with a complex coastline. Boundary-Layer Meteorol. 90, 1-20.

Becker, F., Li, Z.L., 1990. Towards a local split window method over land surface. Int. J. Remote Sens. 3, 369-393.

Caughey, S.J., Kaimal, J.C., 1977. Vertical heat flux in the convective boundary layer. Q. J. R. Meteorol. Soc. $103,811-815$.

Campistron, B., Bénech, B., Dessens, J., Jacoby-Koaly, S., Dupont, E., Carissimo, B., 1997. Performance evaluation of a UHF boundary layer radar in raining conditions based on disdrometer measurements. 8th International Workshop on Technical and Scientific Aspects of MST Radar, Bangalore, India, pp. $334-337$.

Cenedese, A., Monti, P., 2003. Interaction between an inland heat island and a sea-breeze flow: a laboratory study. J. Appl. Meteorol. 42, 1569-1583.

Corsmeier, U., Behrendt, R., Drobinski, P., Kottmeier, C., 2004. The mistral and its effect on air pollution transport and vertical mixing. Atmos. Res. 74, 275-302 (this issue).

Cousin, F., Tulet, P., Rosset, R., 2004. Interaction between local and regional pollution during Escompte 2001: impact on surface ozone concentrations (IOP2a and 2b). Atmos. Res. 74, 117-137 (this issue).

Cros, B., Durand, P., Cachier, H., Drobinski, P., Fréjafon, E., Kottmeier, C., Perros, P.E., Peuch, V.-H., Ponche, J.L., Robin, D., Saï, F., Toupance, G., Wortham, H., 2004. The ESCOMPTE program: an overview. Atmos. Res. 69, 241-279.

Druilhet, A., Frangi, J.P., Guédalia, D., Fontan, J., 1983. Experimental studies of the turbulence structure parameters of the convective boundary layer. J. Atmos. Sci. 45, 853-864.

Finkele, K., Hacker, J.M., Kraus, H., Byron-Scott, R.A.D., 1995. A complete sea-breeze circulation cell derived from aircraft observations. Boundary-Layer Meteorol. 73, 299-317.

Girard-Ardhuin, F., Bénech, B., Campistron, B., Dessens, J., Jacoby-Koaly, S., 2003. Remote sensing and surface observations of the response of the atmospheric boundary layer to a solar eclipse. Boundary-Layer Meteorol. $106(1), 93-115$.

Grimmond, C.S.B., Salmond, J., Offerle, B.D., Oke, T.R., 2002. Local-scale surface flux measurements at a downtown site in Marseille during the ESCOMPTE field campaign. Proc. of AMS 4th Conf. on Urban Environment, Norfolk, USA, 20-24 May 2002. AMS, Boston, MA, pp. 217-218.

Gryning, S.E., Batchvarova, E., 1990. Analytical model for the growth of the coastal internal boundary layer during onshore flow. Q. J. R. Meteorol. Soc. 116, 187-203.

Heo, B.K., Jacoby-Koaly, S., Kim, K.E., Campistron, B., Benech, B., Jung, E.S., 2003. Use of the Doppler spectral width to improve the estimation of the convective boundary layer height from UHF wind profiler observations. J. Atmos. Ocean. Technol. 20, 408-424.

Källstrand, B., Smedman, A.S., 1997. A case study of the near-neutral coastal internal boundary-layer growth: aircraft measurements compared with different model estimates. Boundary-Layer Meteorol. 85, 1-33.

Kerr, Y.H., Lagouarde, J.P., Nerry, F., Ottlé, C., 2002. Land surface temperature retrieval techniques and applications. In: Quattrocchi, D., Luwall, J. (Eds.), Thermal Remote Sensing in Land Surface Processes. Ann Arbor Press.

Lenshow, D.H., Wyngaard, J.C., Pennel, W.T., 1980. Mean-field and second moment budgets in a baroclinic convective boundary layer. J. Atmos. Sci. 27, 1313-1326.

Levitin, J., Kambezidis, H.D., 1997. Numerical modelling of the thermal internal boundary-layer evolution using Athens field experimental data. Boundary-Layer Meteorol. 84, 207-217.

Liu, H., Chan, J.C.L., Cheng, A.Y.S., 2001. Internal boundary layer structure under sea-breeze conditions in Hong Kong. Atmos. Environ. 35, 683-692.

Lothon, M., Campistron, B., Jacoby-Koaly, S., Bénech, B., Lohou, F., Girard-Ardhuin, F., 2002. Comparison of radar reflectivity and vertical velocity observed with a scannable C-band Doppler radar and two UHF profilers in the lower troposphere. J. Atmos. Ocean. Technol. 19, 899-910.

Luhar, A., 1998. An analytical slab model for the growth of the coastal thermal internal boundary layer under near-neutral onshore flow conditions. Boundary-Layer Meteorol. 88, $103-120$.

Jacoby-Koaly, S., Campistron, B., Bernard, S., Bénech, B., Girard, F., Dessens, J., Dupont, E., Carissimo, B., 2002. Turbulent dissipation rate in the boundary layer via UHF wind profiler Doppler spectral width measurement. Boundary-Layer Meteorol. 103, 361-389. 
Mc Clain, E.B., Pichel, W.G., Walton, C.C., 1985. Comparative performance of AVHRR-based multichannel SST. J. Geophys. Res. 90, 11587-11601.

Melas, D., Kambezidis, H.D., 1992. The depth of the internal boundary layer over an urban area sea-breeze conditions. Boundary-Layer Meteorol. 61, 247-264.

Melas, D., Ziomas, I.C., Zeferos, C.S., 1995. Boundary layer dynamics in an urban coastal environment under sea-breeze conditions. Atmos. Environ. 29, 3605-3617.

Mestayer, P., Durand, P., Augustin, P., Bastin, S., Bonnefond, J.M., Bénech, B., Campistron, B., Coppalle, A., Delbarre, H., Dousset, B., Drobinski, P., Druilhet, A., Fréjafon, E., Grimmond, S., Groleau, D., Irvine, M., Kergomard, C., Kermadi, S., Lagouarde, J.P., Lemonsu, A., Lohou, F., Long, N., Masson, V., Moppert, C., Noilhan, J., Offerle, B., Oke, T., Pigeon, G., Puygrenier, V., Roberts, S., Rosant, J.M., Saï, F., Salmond, J., Talbaut, M., Voogt, J., 2004. The urban boundary layer field experiment over Marseille UBL/CLUESCOMPTE: experimental set-up and first results. Boundary-Layer Meteorol. (in press).

Raynor, G.S., Sethuraman, S., Brown, R.M., 1979. Formation and characteristics of coastal internal boundary layers during onshore flows. Boundary-Layer Meteorol. 16, 487-514.

Simpson, J.E., Mansfield, D.A., Milford, J.R., 1977. Inland penetration of sea-breeze fronts. Q. J. R. Meteorol. Soc. 103, $47-76$.

Steyn, D.G., Oke, T.R., 1982. The depth of the daytime mixed layer at two coastal sites: a model and its validation. Boundary-Layer Meteorol. 24, 161-180.

Van de Griend, A.A., Owe, M., 1993. On the relationship between thermal emissivity and the normalized difference vegetation index for natural surfaces. Int. J. Remote Sens. 14, 1119-1137.

Venkatram, A., 1986. An examination of the methods to estimate the height of the coastal internal boundary layer. Boundary-Layer Meteorol. 36, 149-156.

Weill, A., Klapisz, C., Strauss, B., Baudin, F., Jaupart, C., Van Grunderbeeck, P., Goutorbe, J.P., 1980. Measuring heat flux and structure functions of temperature fluctuations with an acoustic Doppler Sodar. J. Appl. Meteorol. 19, 199-205.

Wyngaard, J.C., 1983. Lectures on the planetary boundary layer. In: Lilly, D.K., Gal-Chen, T. (Eds.), Mesoscale Meteorology: Theories, Observations, and Models. D. Reidel, Dordrecht, The Netherlands.

Yoshikado, H., Kondo, H., 1989. Inland penetration of the sea-breeze over the suburban area of Tokyo. Boundary-Layer Meteorol. 48, 389-407. 